\title{
New Light and Old Texts: Galen on His Own Books
}

\author{
P. N. Singer
}

My aim in this chapter is to show how the new material from the $\pi \varepsilon p i$ a $\lambda v \pi i a s$ (Ind.) contributes to our understanding of Galen's attitude, practices and intentions in relation to the composition and distribution of his own books. The new text, I suggest, not only provides fresh perspectives but, perhaps more importantly, assists us to evaluate and see more clearly the evidence which was already available in the other most relevant texts in this area, especially My Own Books (Lib. Prop.) and The Order of My Own Books (Ord. Lib. Prop.) The 'new light' is thus shed in a process of mutual illumination between $\pi \varepsilon p i$ $\dot{\alpha} \lambda u \pi i a s$ and other texts, rather than by the sudden availability of radically new and divergent information.

\section{1 \\ Galen's Losses}

A good starting-point for this discussion might be: which of Galen's own writings did he actually lose in the fire which is the subject of $\pi \varepsilon p i$ a $\lambda u \pi i a s$ ? The answer turns out to be surprisingly elusive. Let us consider Galen's account of his losses overall. They are summarized in brief at sections 4-6. Galen lists: items made of precious metals; financial documents; drugs (both simple and compound) medical instruments; books (both copies of classical writings corrected in his own hand his own compositions); antidotes. The list is then elaborated, with, in particular, a lot more detail about the books, between this point and section 30 , and with a further category, that of pharmacological recipes, added and discussed in some detail at $31-36$.

For simplicity, then, Galen's losses may thus be listed under two main heads: books and other possessions. ${ }^{1}$ The books can again be divided: into books by other people and Galen's own compositions. Now, we would probably think

1 The category of pharmacological recipes, which in a sense could be thought of as books, is interesting here: they seem in fact to be considered by Galen as valuable commodities, rather like the materia medica itself, not as texts in any normal sense. This relationship of such unique, collectible, recipes to Galen's own pharmacological writings presents an interesting problem, though it cannot be explored here.

(C) P. N. SINGER, 2019 | DOI:10.1163/9789004383302_006

This is an open access chapter distributed under the terms of the prevailing CC-BY-NC-ND License at the time of publication. 
that the loss of his own compositions would be what Galen - or any author would find most agonizing (or, as Galen has it, would create the greatest challenge for his absence of distress). Certainly, as we shall see, there are some specific books of his own composition that do fall into that category. But Galen begins his discussion with a different category of works, and it is the irreplaceability of these, in particular, that he emphasizes: items in his personal library of other authors. ${ }^{2}$ At section 5, Galen distinguishes three sub-categories of these:

(i) rare works in his collection, which are irreplaceable because the only other copies would have been in the Palatine library, destroyed at the same time as his (12-13);

(ii) copies of works which are not themselves rare, but represent particularly accurate editions of the text in question, because they were prepared by a particular author or scholar (an example is Panaetius' copy of the works of Plato), or because they were, in some sense, autograph $\operatorname{copies}^{3}(14)$;

(iii) copies of works which do not represent good editions in this way, but where Galen has himself marked corrections to scribal errors - right down to details of punctuation - so as to 'provide almost a new edition' of the work in question; and this includes also some texts of which there is no copy elsewhere. This third category includes works of Aristotle, Theophrastus, Chrysippus and 'all the ancient doctors' $\left(15^{-17}\right)$.

The first thing that emerges from all this is the extraordinary level of Galen's scholarly activity: collecting, finding good editions, and correcting and preparing new editions, of a whole range of texts. Texts which include not just those of authors like Plato and Hippocrates, who, as we know, are central to his own intellectual output, but also a whole range of others of much less central philosophical interest, or in some cases just of linguistic interest - Theophrastus, Eudemus, Chrysippus, the orators. ${ }^{4}$

The impression is radically reinforced when we turn (20) to the first explicit mention of a work by Galen himself which was lost: a work on 'words in Attic

2 See above, 'Note on ms Vlatadon 14' (henceforth: 'Note'), text (b): if one were to read

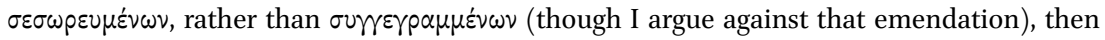
Galen would not be mentioning his own writings until some way down the list of losses.

3 On the differences in interpretation on this point, see 'Note', text (c). On the interpretation of 'Panaetius' Plato', see Gourinat, J.-B. (2008). 'Le Platon de Panétius: à propos d'un témoignage inédit de Galien', Philosophie Antique 8, 139-51.

4 As discussed in the 'Note', there is some uncertainty as to which specific texts or manuscripts are being discussed; but the text certainly gives evidence not just for Galen's intense scholarly activity, especially but not only on works in the Aristotelian tradition, but also for the availability to him of a far greater range of works (and or different manuscript traditions) than was previously known. 
Greek and everyday language ... in two parts, one drawn from Old Comedy, one from prose-writers. 5 The work seems to have taken the form of a glossary, explaining to a contemporary audience the usage of the old Attic authors in relation to a whole range of selected words, especially those of significance to medicine and diet (24-27). This, too, then, was a manifestation of his scholarly activity, and a very considerable one, if we are to take seriously the 'forty-eight large books' mentioned, on prose writers alone $(28) ;{ }^{6}$ and indeed, it is perhaps significant that Galen, in making this transition to discuss his own work as opposed to the editions of others just discussed, seems to make no very clear distinction in his syntax: the lost work on Old Comedy appears almost as a continuation of the previous category. And further light on this categorization follows at 29: Galen says that none of the above losses caused him distress ... 'any more than the loss of my own notes (hupomnēmata)'; these latter, he goes on to say (29), were of two sorts: some which had been written up so as to be useful to others, some for a 'reminding' purpose (eis anamnēsin) which was just for his own use.

We shall return to that discussion of hupomnèmata, with its distinction of categories, in due course. At this particular point (29) he gives no further elaboration, but rather proceeds immediately to two other categories: first again a distinctly scholarly kind of product - that of the 'very many summaries by heading of a very large number of works on medicine and philosophy'; secondly, the recipe collection (which we have already mentioned above). We shall also return in due course to these notes and summaries, as well as to the further remarks on the losses in the fire, especially in Lib. Prop. But only one further work is mentioned by name in the course of Ind. as having been lost in the fire, in addition to that on Old Comedy: his 'treatise on the composition of drugs' (37). But that, surely, is not all. There is, indeed, another characterization of the lost works, though without any titles, in the passage immediately preceding the mention of the work on Old Comedy, at 21-23a: there Galen refers to the loss of copies of 'all his works for distribution' (panta ta pros ekdosin). Before addressing the question of the specific reference of that phrase in its context here, it will be helpful to consider the broader question of Galen's book production and book distribution as evidenced elsewhere in Galen's writings, in particular in Lib. Prop. We might start from what at first blush appears a

5 The second part, he goes on to say (20), does survive (though it has not come down to us), because a copy was taken and transferred to his country home in Campania.

6 The length indeed seems enormous, although an explanation has been offered in terms of the glossary-style layout: each lexical item would have a fresh line. See del Mastro, G. (2012).

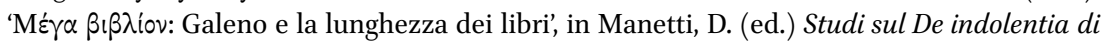
Galeno, 33-62. 
puzzling conundrum: why, given the loss of what Galen describes at one point as 'all my books' (50), do the extant works of Galen occupy a shelf or more in the modern library? How, given the disaster of the fire, is he still the most voluminous author we possess from antiquity?

Of course, the answer, in broad terms, is fairly simple. A work destroyed in the fire was only lost if it had not already been copied and if such a copy or copies - did not survive elsewhere. This simple answer, though, conceals a rather complex variety of possibilities - possibilities contained or concealed in a number of brief remarks Galen makes in relation to the practice and process of book distribution, or ekdosis. Since (a) there has been a considerable volume of recent scholarship on this subject, much of it based on the evidence of Galen, (b) I believe the conclusions of much of this scholarship to be misleading in certain key respects and (c) the new text, $\pi \varepsilon p i \dot{\alpha} \lambda u \pi i \alpha \varsigma$, sheds further significant further light in this area, a detailed account of the problem may be of value.

There is a conceptual distinction in ancient discussions of books and their destination audiences, between an apparently private or closed transaction, carried out between friends or within a circle of students or associates, and an apparently wider, more formal kind of distribution or 'publication' of a text; and typically the verb didonai and cognates are used for the former, and the verb ekdidonai and cognates - especially the noun ekdosis - for the latter. ${ }^{7}$ In a well-known passage of My Own Books (to which we shall return) Galen himself describes a situation whereby works intended to be read only within such an intimate circle, or in some cases only by students at a particular level in their development - works which he typically describes as having been written in response to specific requests from these sources - have been copied and circulated without the author's consent, and thus gained a wider distribution. Such works are explicitly or implicitly characterized as lacking the completeness which one would expect for a work intended for a larger audience. In some cases, a work circulating in this 'bootleg' form, with errors, finds its way back to the author, and is corrected by him before further distribution takes place. An

7 Classic studies of the question of ekdosis and book circulation in the ancient world are van

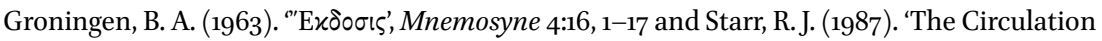
of Literary Texts in the Ancient World', $c Q$ 37, 213-23. 
important element of the process of ekdosis, as we shall see that the new evidence from $\pi \varepsilon p i \dot{\alpha} \lambda v \pi i a \varsigma$ makes clear, is the depositing of a copy of one's work in a public library; this - in a process also described by Galen in the new text enables interested readers not only to consult the work in situ, but to have further copies made for their private use. It should also be noted that $e k d o s i s$ is also the term used for an 'edition', or particular version, of a text, especially in the sense of the scholarly edition of a classical author by a particular scholar e.g. Bacchius' ekdosis of Hippocrates - without any reference to a destination audience or process of distribution.

Now, it should always be borne in mind that the process of publication, or distribution, referred to in such discussions has very little in common with those familiar from the modern period. There is no multiple production by the author, or by some 'publisher', of copies for circulation: both the act of 'giving' a work to a friend and that of 'giving-out' a work to a wider public consist, from the author's point of view, of the handing over, or making available, of a single copy, from which further copies may be made. Differences in manner of distribution depend on how many people are given access, and how many further copies are made. This in turn may, of course, depend in some way upon the work's initial manner of composition, its genre and the author's intentions; in this area, however, it is, as we shall see, very difficult to make clear statements or arrive at clear distinctions of type.

But let us look at this process of distribution, and what Galen tells us about it, in a little more detail, beginning with the evidence of My Own Books and The Order of My Own Books. A clear bipartite distinction has been made by some scholars, following the conceptual distinction given above, between works written for wide circulation or 'publication', on the one hand, and those intended for private use, or circulation within a small circle of friends or colleagues, on the other; and certain passages of Galen's My Own Books have provided an important part of the evidence for this supposed pros ekdosin/ou pros ekdosin distinction. ${ }^{8}$ Let us look at what Galen actually says in this regard. We

8 See in particular Dorandi, T. (2000). Le stylet et la tablette: dans le secret des auteurs antiques and (2007). Nell' officina dei classici: come lavorano gli autori antichi (Dorandi's analysis is not confined to Galen, but uses the Galenic material as an important part of his argument; other relevant composition practices are those mentioned by Iamblichus, Vit. Pyth. 23,104, talking of hupmnēmastismoi kai huposēmeiōseis; and of Neoplatonist commentators on Aristotle who divide his work into hupomnēmatika and suntagmatika); Gurd, S. (2011). 'Galen on E' $x \delta \circ \sigma \varsigma \varsigma^{\prime}$, in Schmidt, T. and Fleury, P., Perceptions of the Second Sophistic and its Times: Regards sur la seconde sophistique et son époque, $169-84$. The bipartite distinction seems to have become widely accepted by scholars working on Galen's literary activity and self-presentation; 
shall start with a passage fairly late in My Own Books, in which Galen is listing his works on logical demonstration.

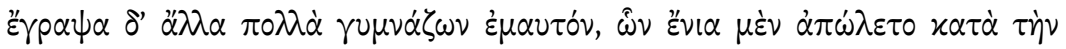

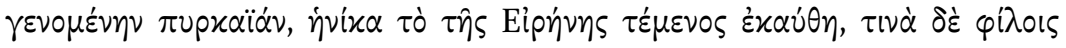

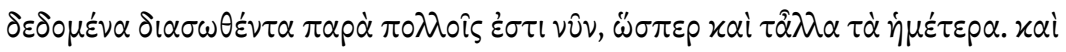

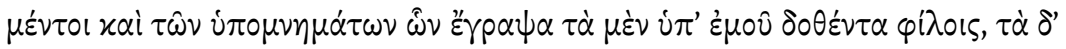

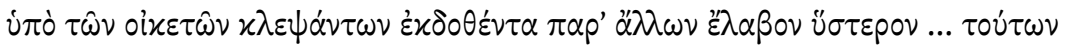

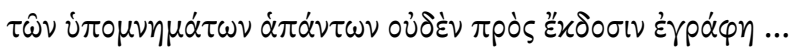

I wrote many others as an exercise for myself, some of which perished in the fire in which the Temple of Peace was destroyed, but some had been given to friends and now survive in copies in many people's possession, just like our other works. Even of the hupomnemmata that I wrote, some were given by me to friends, while others, which had been stolen and distributed by servants, I later received back from other persons ... None of these hupomnèmata were written for distribution (pros ekdosin) ...

Lib. Prop. 14 [11] (XIX.41 K. = 166,1-8 Boudon-Millot; XIX.42 K. = 166,18-19 Boudon-Millot) ${ }^{9}$

This text does indeed seem to follow our terminological distinction: Galen himself 'gives' (dedomena) works to friends; his household staff steal works and 'give them out' or distribute (ekdothenta) them more widely. Two other things, however, are striking in this passage. One is that although Galen identifies a category of works as 'for his own exercise' (gumnazōn emauton - we shall consider this description further below), he then adds that he gave such works to his friends. Such a slippage, whereby a type of work which is claimed to be for private use is in fact given to others, gives us an early warning of the difficulty that we shall have in identifying clear categories of works for different destinatees in Galen's accounts. ${ }^{10}$ Even more revealing, though, is that though

see also Boudon-Millot, V. (2007). Galien, Tome 1; Mansfeld, J. (1994). 'Galen's Autobibliographies and Hippocratic Commentaries', in Prolegomena: Questions to be Settled Before the Study of an Author, or a Text; Vegetti, M. (2013). Galeno: nuovi scritti autobiografici.

9 Translations are my own unless otherwise stated. The chapter numbers of Lib. Prop. were altered by the discovery of the Vlatadon ms: in references here the new number is followed by the old in square brackets.

10 Even more strikingly - and even more problematically from the point of view of the literalness with which the terminology can be taken - Galen elsewhere uses exactly the same phrase in a general characterization of his motivation in writing: he always used to write either 'as a favour to friends or gumnazōn emauton', $M M$ 7.1 (X.456 K.). 
these 'private' works were given only to friends, they are now preserved and in the hands of many. Galen here not only sheds light on a process whereby 'giving' a book to friends will lead to its wide ( $\pi \alpha \rho \dot{\alpha} \pi 0 \lambda$ oîs) distribution; he also makes clear implicitly that (in spite of the explicit dismay expressed, as we shall see, elsewhere at such unauthorized distribution) such wider distribution was to be expected and, in the case of an unexpected loss of his own copy, might even be relied upon to fill the gap.

The phrase 'just like our other works' (hōsper kai talla ta hēmetera) is tantalizing here, and again we shall see similar phrases elsewhere: it is, by implication, certainly, the term opposed to 'as an exercise for myself', and so seems to suggest a non-private category - the works that Galen did intend for distribution. But this is not stated. What, then, of the category of hupomnemata, which is introduced immediately after these other two categories (the sequence is: works of 'self-exercise'; 'our other works'; hupomnèmata)? This term, as we shall discuss further below, has a potentially very broad reference in Galen,"11 although it is also true that at some point it became the standard Greek word for 'commentaries'. Whatever the term refers to, Galen asserts that none of the works in that category - though some achieved circulation through having been given to friends, and some through theft by his servants - was intended for ekdosis. Given the context - Galen goes on to list a number of works on specific classical texts of logic - it seems that the translation 'commentaries' is appropriate here. This would mean that Galen is stating that none of his commentaries on works of logic was intended for ekdosis; and this, as we shall see, directly mirrors what he says about his commentaries on Hippocrates in ch. 9 [6]. To sum up: Galen has here identified three categories: about two of them he has made clear that they were not intended for distribution, though distribution in many cases in fact took place; the reference of the third, talla ta hêmetera, is quite vague. We should, finally, consider the context of this passage, beginning as it does with a mention of 'many other works': what are the previously-mentioned works with which these 'private' works are contrasted? One might think that the phrase must follow on a list of works which definitely are for ekdosis. The truth is rather more complicated. In fact, after a lengthy preamble about his own formation in logic and the shortcomings of certain teachers and philosophers, the chapter has so far mentioned one other work by name, before moving to the 'private' categories of the above passage. Certainly,

11 On this point see von Staden, H. (1998). 'Gattung und Gedächtnis: Galen über Wahrheit und Lehrdichtung', in Kullmann, W., Althoff, J. and Asper, M. (eds), Gattungen wissenschaftlicher Literatur in der Antike, 65-94, pointing to lack of any clear distinction between the different nouns which Galen uses in reference to his works. 
it is a work - his De demonstratione - which he strongly recommends to the serious student at the beginning of his studies; clearly, then, he must both believe and intend it to have a fairly wide distribution, at least amongst serious students. Yet there is, it should be emphasized, no explicit mention of a pros ekdosin category, to contrast with the term ouden pros ekdosin which we have noted. Indeed, as we shall see, Galen's own deliberate act of distribution, of ekdosis, in this text is extremely elusive.

A converse example to the above one of works not 'given out', but nevertheless extant is provided by the major pharmacological treatise, De compositione medicamentorum per genera: here, Galen gives an account of books which have been distributed ( $\dot{\varepsilon} x \delta 0 \theta \dot{\varepsilon} v \tau \omega \nu, \pi \rho 0 \varepsilon x \delta 0 \theta \varepsilon \dot{\varepsilon} \tau \omega \nu)$, but are not extant. In the proem to the now extant version of this work, Galen claims that he is rewriting the first two books, which were lost in the fire, and that he is doing so even though they had previously been distributed:

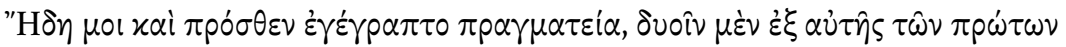

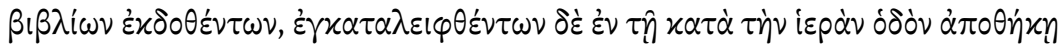

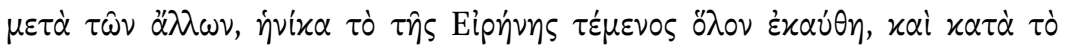

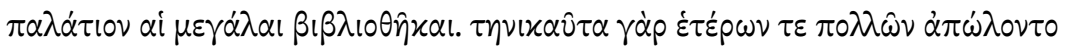

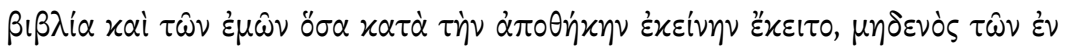

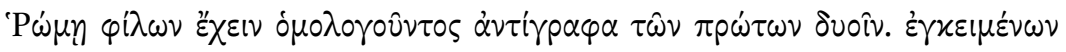

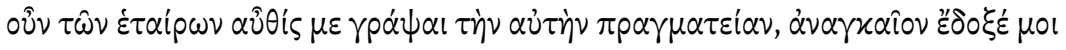

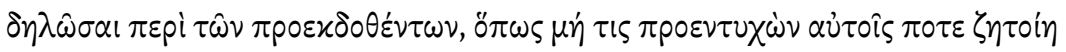
$\tau \dot{\nu} \nu \alpha i \tau i \alpha \nu \tau 0 \hat{~ \delta i ́ \varsigma} \mu \varepsilon \pi \varepsilon \rho i \tau \hat{\omega} \nu \alpha \dot{\tau} \tau \hat{\omega} \nu \pi \rho \alpha \gamma \mu \alpha \tau \varepsilon \dot{\sigma} \sigma \alpha \sigma \theta \alpha \mathrm{l}$.

I had written a treatise previously, too, of which the first two books had been distributed, and also deposited in my storehouse alongside the others, when the whole of the Temple of Peace was destroyed by fire, as well as the great libraries on the Palatine. The books of many others perished at that time, as did all those of mine which were located in that storehouse; and none of my friends in Rome admitted to having copies of the first two books. Since, then, my followers prevailed upon me to write the same treatise again, I thought that I should give this explanation regarding the previously distributed books, in case anyone in the future finds them and wonders why I should have written a treatise twice on the same subject.

Comp. Med.Gen. 1.1 (XIII.362-3 K.) ${ }^{12}$

12 Cf. the vaguer reference to the loss in Ind. 37, on which more below. 
By contrast with the previous case, where informal 'giving' leads to widespread copying and distribution, here books were 'given out' (as well as being deposited in Galen's storehouse) but, after the fire of 192, cannot be found, even amongst friends in Rome. The specific phrase 'in Rome', combined with the implied expectation that the lost books may after all turn up again, suggest that Galen may have grounds to believe that the ekdosis has led to the preservation of copies elsewhere, perhaps in a library in Asia. ${ }^{13}$ But another point should be made here: elsewhere in this very same work Galen makes clear that its expli-

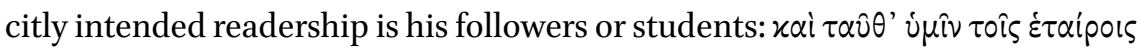

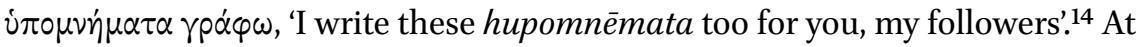
least formally, this is a work for a group of intimates; already here, then, we see that the term ekdosis may be used in relation to works which are not, formally, intended for a wide audience. (And note that in the above text, again, Galen refers to a process of distribution that has taken place without explicitly admitting any personal role in it.) But let us return to My Own Books, and to the preface of that work - a central text on which scholarship identifying the pros ekdosin / ou pros ekdosin distinction has based itself.

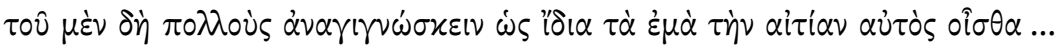

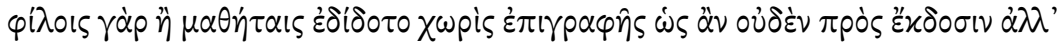

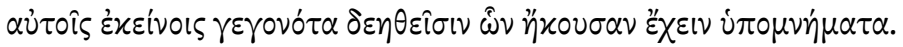

Well, as for the fact of my works being passed off by many people under their own name you know the reason yourself: ... it is that they were given without inscription to friends or pupils, since they had been written in no way for distribution, but simply at the request of those individuals, who had desired a written record of lectures they had heard.

Lib. Prop. praef. (XIX.10 K. = 135,11-20 Boudon-Millot)

13 On this process see Ind. 21 and the discussion of that passage below.

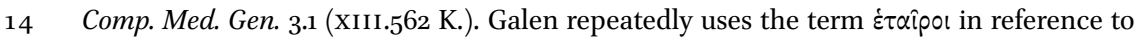
the intended audience of his major medical works. It seems to me, pace Mattern, S. P.

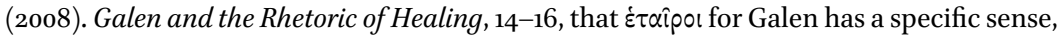
essentially referring to his pupils, or close followers of his medical instruction (a claim which I hope to support in detail in a forthcoming article). But even if this specific in-

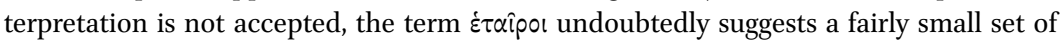
associates, not a wider audience. For an important recent discussion of the intellectual community implied by or addressed in Galen's medical works see van der Eijk, P. 'Galen and the Scientific Treatise: A Case Study of Mixtures', in Asper, M. (2013). Writing Science: Medical and Mathematical Authorship in Ancient Greece, 145-75. 
Again, the action which Galen is claiming as his own is didonai, not ekdidonai: that is, he himself gives books to his friends or pupils; other people have been responsible for the wider distribution. But note that what Galen is very definitely not doing, here, is identifying two categories of books, one for distribution and one not; rather, he is making a general statement about his writings (even if quite how general is not perfectly clear ${ }^{15}$ ), and putting this forward as a reason for people having appropriated his works as their own. The notion of an opposite implied by the negative $0 \dot{v}(\delta \dot{\varepsilon} v) \pi \rho \partial^{\prime} \varsigma$ हैx $\delta \circ \sigma \nu$, that is to say an actual

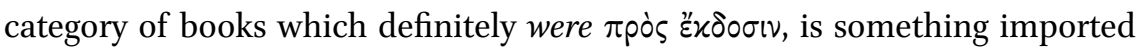
into the text - if we choose to import it. Nothing of that sort is stated here, and without support from other contexts this passage would be taken as referring to his books in quite general terms.

What, then, of those other contexts? A few lines later, Galen continues:

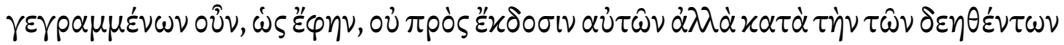

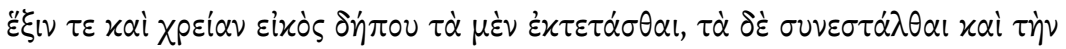

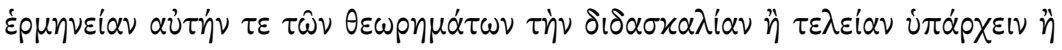

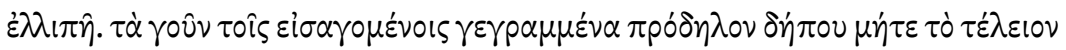

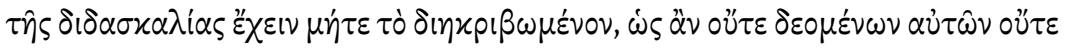

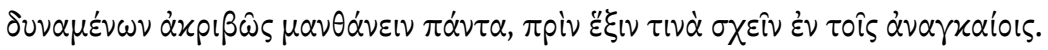

Since, then, as I have stated above, they were written not for distribution but to fit the particular level and needs of those who had requested them, it follows naturally that some of them are rather extended, while others are compressed; and that their manner of communication, and indeed the actual exposition of theoretical material, vary in their completeness. Those works which were written for beginners would, quite evidently, be neither complete nor perfectly accurate in their teaching. That was not their requirement - nor would such individuals have been able to learn the whole subject matter accurately, until they had first reached a certain basic level in the fundamentals.

Lib. Prop. praef. (XIX.10-11 K. = 136,4-13 Boudon-Millot)

15 It would, perhaps, be possible to take ouden in this sentence not adverbially (as above, cf. the 1997 translator, 'with no thought for', similarly Boudon-Millot: 'aucunement') but pronominally (albeit with a mild anacolouthon, shifting from the plural of ta ema and gegonota to the singular): 'none [of them was] written for distribution'; that would make the usage directly parallel to that already observed in the passage from ch. 14 [11]. 
He then proceeds to explain that certain works intended purely 'for beginners' circulated more widely, because they had not been explicitly so labelled. The subject of the whole paragraph, however, that referred to by gegrammenon at the beginning of this extract, is exactly the same as that of the previous extract: it is the general 'my books'. Galen is still telling a story about his writings in general, not a sub-category of them; indeed, he is analysing a problem which arises precisely from the very wide differences that exist across all his writings (because of their different original destinatees).

Let us turn to the final passage of My Own Books which sheds light on Galen's own account of his attitude to ekdosis - again a passage which has been central to constructions of a distinction of 'private' and 'public' works in the output of Galen, and indeed of other ancient authors. It comes in the chapter where he makes the transition to discussion of his works of Hippocratic commentary. The passage has been interpreted as stating that Galen wrote such works in two distinct styles, with two distinct sets of recipient in mind, and at two distinct periods. That is, after a period in which he had written commentaries purely for his own use or for that of his close associates, he made an abrupt transition, in response to a particular event, to the writing of works intended for a wider audience and engaging in detail with rival commentators. In the former category, then, are the commentaries on Aphorisms, Fractures, Joints, Prognosticon, Regimen in Acute Diseases, Wounds to the Head and Epidemics I, in the latter those on Epidemics II, III and VI, Humours, Nutriment, Prorrhetic, Nature of Man, De officina medici and Airs, Water, Places. But this, we shall see, is not what Galen actually says; moreover, even if it could, on a simplistic reading, be taken to be what he says, such an account is substantially undermined by the much fuller, more detailed, chronological account of the same subject which he gives elsewhere in his writing.

Before coming to the precise words in which Galen distinguishes and lists his different Hippocratic commentaries, let us look at the preamble to that. This passage itself contains some problems, both textual and interpretive, which are in need of elucidation; it will therefore be worth our while to consider it in some detail, and with the assistance of an apparatus criticus for the problematic passages.

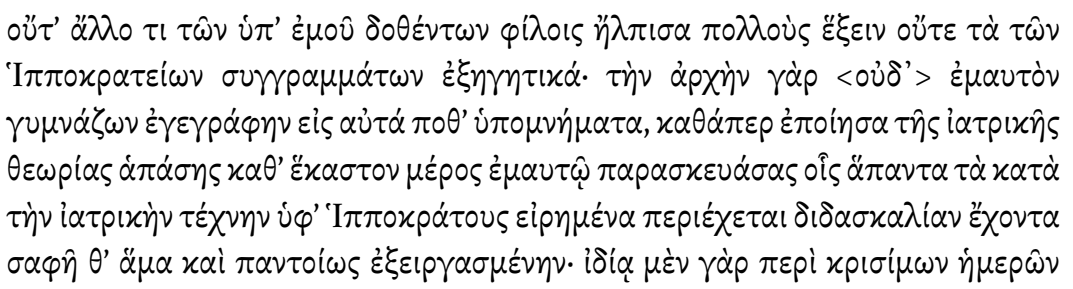




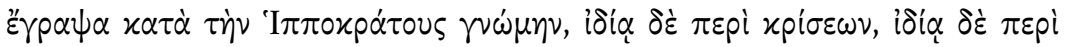

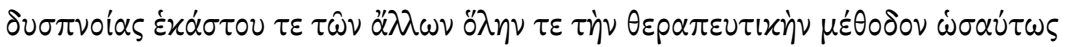

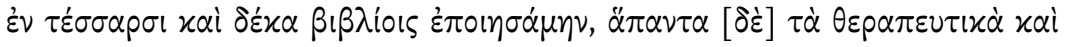

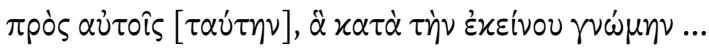

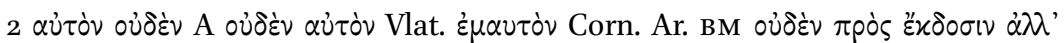

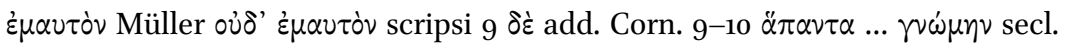

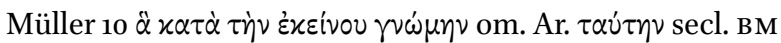

Before proceeding we must consider some textual uncertainties. In line 2,

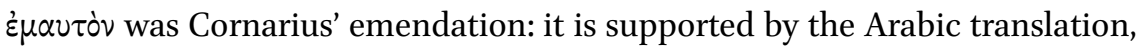

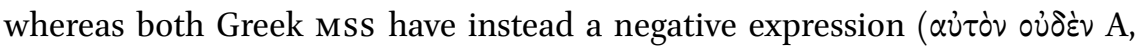

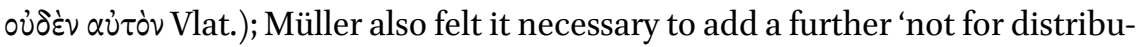
tion' comment to make sense of the passage. But one should consider whether the negative, supported by all the Greek MSs, may after all be preserved: if we

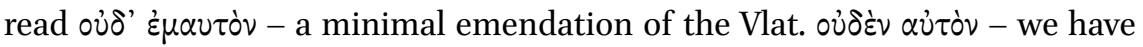
a solution which makes sense of the Greek MS tradition while also preserving

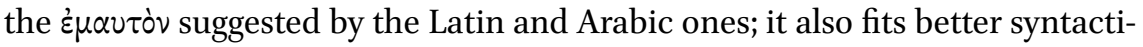
cally with $\pi \circ \theta^{\prime}$ ' in the next line. The sense would then be: 'To begin with I did not ever write notes/commentaries on them even as an exercise for myself, as I did in each individual part of the whole art of medicine ...'; and this in fact would be perfectly consistent with the explanation that he goes on to give: he did not need to write commentaries on Hippocrates because Hippocrates' views were already contained in Galen's individual medical works. The difference, on this reading, is that Galen is claiming not even to have made 'private' commentaries at an earlier stage, whereas according to both Müller's and Boudon-Millot's readings he is saying that at that time he wrote only private commentaries. My emendation would of course make the present discussion even less relevant to the chronological 'private-public' distinction that has been perceived: Galen is not writing (commentary-style) private notes early on, and moving to works for publication later, because he was not writing such notes early on at all. Such a chronological distinction of types of commentary activity is not in play. This also seems consistent with what is said in Hipp. Epid. III (see n. 25 below): at the earliest stage he is simply not writing commentary on Hippocrates.

The above emendation will not seem convincing to all; nor is it essential to my argument in what follows. It should, however, be noted that two quite substantial interpretive difficulties remain, if we do not adopt that negative. On such a (non-negative) reading, Galen identifies a personal-exercise category (let us call it ' $\mathrm{A}$ ') of Hippocratic commentaries which he wrote at an early stage, and sets it alongside another category or writings ('B'), also termed hupomnēmata, introduced by the phrase $x \alpha \theta \dot{\alpha} \pi \varepsilon \rho$ ह่ $\pi$ oin $\sigma \alpha$. The first problem, 
then, on this reading, is that it is quite difficult to make sense of the opposition between categories A and B. B must now be hupomnemata on the whole of medicine, considered subject by subject as opposed to by Hippocratic treatise. Such an opposition makes sense; but what relationship between category $\mathrm{B}$ and the Hippocratic texts is Galen then making in the phrase that follows, ois ... $\dot{\varepsilon} \xi \varepsilon i p \gamma \alpha \sigma \mu \varepsilon \dot{\varepsilon} \eta \nu$, which must mean something like 'in which are contained all things stated by Hippocrates in relation to the art of medicine, things which have an exposition ${ }^{16}$ which is both clear and completely elaborated'? Having made the distinction between categories A (private-exercise notes on Hippocrates) and B (similar notes on each branch of medicine), Galen is immediately insisting on the close relationship of the latter set of notes to Hippocratic texts - a relationship then further insisted upon by the description of these medical works as 'according to the opinion of Hippocrates' $x \alpha \tau \dot{\alpha}$

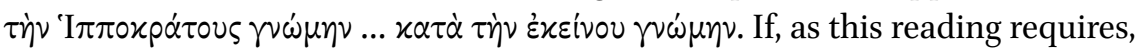
Galen is identifying two parallel sets of 'exercise' works, the first on works of Hippocrates, the second on branches of medicine, the distinction between them seems to collapse as he insists on the essentially Hippocratic nature of the latter.

The second, related, problem is that category B includes the works Critical Days, Crises and The Therapeutic Method. These major medical works - so far from being for 'distribution' in any sense - are, on this reading, claimed by Galen to have been written as a private intellectual exercise: 'I made notes for my own exercise, as I did in the individual parts of medicine [and then the reference to those works]'. The adoption of the negative makes the association less close: rather than considering two parallel sets of 'exercise' notes, it is then at least possible to take the $x \alpha \theta \dot{\alpha} \pi \varepsilon p$ ह่ $\pi$ in $\sigma \alpha$ clause, more loosely, as referring simply to the writing of hupomnemata, rather than as picking up the

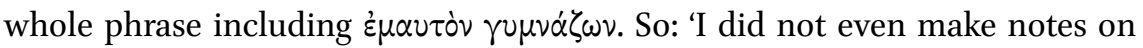
Hippocratic works for my own exercise; I did [by contrast] make notes on the individual parts ...'

16 The phrase raises a further interpretive problem: does the participle है $\chi 0 v \tau \alpha$ refer to the statements of Hippocrates or to those statements as mediated by Galen; in other words, is the 'clear exposition' that of Galen in his explication or that of the master? Either interpretation brings problems. On the one hand, talk of clarity and fulness of Galen's exposition, as opposed to Hippocratic concision, would seem consistent with what Galen says elsewhere about the relationship between his writing and Hippocrates' and about the function of commentary; it might seem odd, indeed, for him to refer to Hippocrates' own writings in such terms. On the other hand, such a reading is grammatically difficult: it is

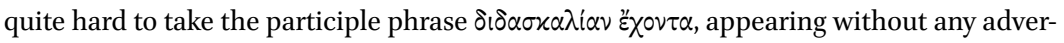
sative particle, as suddenly introducing Galen's, not Hippocrates', contribution. 
The end of the passage brings more textual and interpretive uncertainties. Müller secluded the whole of the phrase $\ddot{\alpha} \pi \alpha \nu \tau \alpha$ to $\gamma \nu \omega \dot{\mu} \mu \eta \nu$, thus removing the second statement of the double function of Galen's texts as medical and Hippocratic; yet it seems no more challenging that what has already been said, and is supported by both Greek Mss and (as far as aijzoîs), by the Arabic. However, the phrase makes better sense without Cornarius' $\delta \dot{\varepsilon}$, for then it can

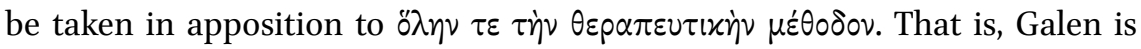
glossing 'the whole of The Therapeutic Method' with the phrase 'all the therapeutics and also what is in accordance with Hippocrates' view'; and this agrees perfectly with the sense of the argument so far. Although the words from xai

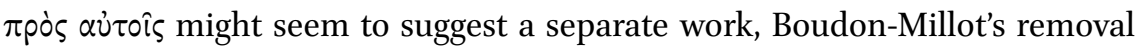
of the ungrammatical $\tau \alpha \dot{\tau} \tau \eta \nu$ assists us in seeing that this is not the intention; in any case (see further below), to what additional work could Galen possibly be referring? On balance, this whole last phrase from $\ddot{\pi} \pi \alpha \nu \tau \alpha$ must be taken appositionally: again, Galen is presenting his own works of therapeutics as simultaneously works on Hippocrates.

To summarize: Galen is about to say that he did not, in an earlier phase, write line-by-line commentaries of Hippocratic works, because he found that unnecessary. The present passage is laying the foundations for this claim by making the point that all Galen's own works on specific medical topics 'contain all things stated by Hippocrates in relation to the art of medicine, things which have a form of exposition which is both clear and completely elaborated'. This is, indeed, a remarkable claim. The interpretive focus on the apparent 'privatepublic' distinction, and on the classification of the Hippocratic commentaries that follows has, perhaps, taken attention away from how remarkable it is. Galen is saying that his own works on medical topics - central works like Critical Days, Crises and The Therapeutic Method - in fact perform the function of commentaries on Hippocrates: they are in a sense proto-commentaries, or adequate commentary-substitutes; and he is stating this as his reason for his having carried out no direct commentary work on Hippocrates until a late stage in his career. The only way of resisting this interpretation is by taking

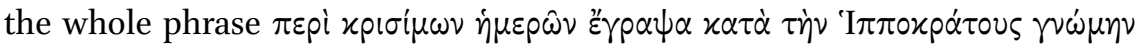
to refer to the composition of a specific work 'On Critical Days According to Hippocrates' - which is indeed what the phrase seems most naturally to mean - and therefore taking this whole passage to refer to works specifically on Hippocrates' views. Yet the context, amid the known works Crises and The Therapeutic Method - especially with the specific reference to The Therapeutic Method as having fourteen books, which makes it clear that this is the extant The Therapeutic Method - and the absence of any reference elsewhere to these separate 'According to Hippocrates' works, makes this clearly impossible. 
And we should note that this very striking claim, in the latter part of the passage quoted, remains whether or not we adopt my proposed reading in the first lines. My suggestion, however, is that doing so gives us a progression of thought which is more consistent with this claim: Galen is explaining his non-writing of direct commentaries on Hippocrates (even for personal use) by the fact that his other works at this stage were, in a sense, commentaries on Hippocrates. A couple of points of clarification, however, should be made before we proceed. One is that the term idiai in this passage must, indeed, be taken to mean 'specifically', not 'privately.'17 In such contexts Galen uses the term in the former sense quite regularly. The distinction at this point is not between 'for private use' and the (unstated) opposite, 'for publication', but between an organization of his own literary output according to specific medical subject (while simultaneously clarifying Hippocrates' views), and the alternative activity of writing line-by-line Hippocratic commentaries. Galen is not here outlining a privatepublic distinction within his own works. What he is doing is either - on any of the previously accepted readings of the above passage - explicitly insisting on the private character of even his most central works of medicine, which he claims to have been written in a process of intellectual self-exercise, or at least - on my reading - associating them quite closely with that intellectual activity.

Let us then offer a translation of this whole introductory passage, before proceeding to that in which Galen does, apparently, mention an ekdosis of his own Hippocratic commentaries.

As with my other works given to friends, so especially with the works of Hippocratic commentary, I had no expectation that they would reach a wider audience. In the first instance, indeed, I did not ever write notes on those works even as an exercise for myself - as I did [on the other hand], preparing them for myself, in each individual area of medical theory notes by means of which is contained all that Hippocrates had said of relevance to the art of medicine, having a clear and fully elaborated exposition. For I wrote specifically on critical days, in accordance with Hippocrates' views, but also specifically on crises, specifically on difficulty in breathing, and on all the other subjects; and in the same way I produced the whole therapeutic method, in fourteen books: [that is to say,] all of therapeutics, and in addition those things which are in accordance with his views.

Lib. Prop. 9 [6] (XIX.33-4 K. = 159,10-160,1 Boudon-Millot)

17 As Boudon-Millot ad loc.: 'à usage privé'. 
That status of The Therapeutic Method as - not, to be sure, for personal exercise, but - 'purely for a friend', is, indeed, asserted within the work itself. ${ }^{18}$ And this same idea, that Galen 'gave to friends' many of his central medical works with the further claim that he would not have done so if he had known that they would be distributed (ekdothēsesthai) to the unworthy - is asserted also in the autobiographical work, Prognosis. ${ }^{19}$ In the latter case, the works mentioned include not only Crises but also the major treatises in the pulse, all of which, again, feature prominently in the curriculum of study in My Own Books.

The fact that a work as central to his own corpus as The Therapeutic Method can be referred to in the category 'given to friends' and 'with no expectation that it would reach a wider audience' suggests two rather important things. The first is that the 'giving' in question here can include formal literary dedication to a named addressee (as indeed appears in The Therapeutic Method), rather than some private transaction; the second is the disingenuous nature of the 'not-for-distribution' claim itself. The claim that works were never, in the first place, intended for a wider audience, and not written with a view to reputation, is indeed a repeated one throughout Galen's work; ${ }^{20}$ it is undoubtedly, at least at some level, a literary trope, whereby the author anticipates or defends himself against criticisms based on a work's apparent incompleteness or other shortcomings. ${ }^{21}$ This is not, however, to deny the historical reality behind such claims. There is no reason to doubt, either that the dedicatees of The

18 See $M M 7.1$ (Х.456-7 K.).

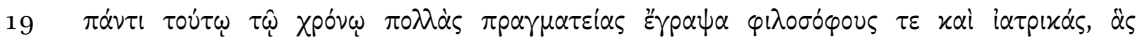

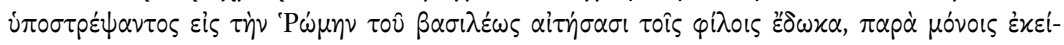

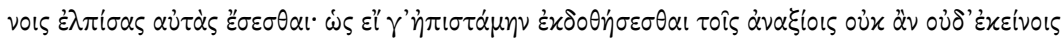
है $\delta \omega x \alpha$, Praen. 9 (XIv.650-1 K. = 120,1-4 Nutton): the period referred to is the same one mentioned in Lib. Prop. as that in which he 'wrote up' his main medical and scientific works, on which see pp. ${ }^{122-} 3$, with n. 45 , below.

20 Above we saw the example of $M M$, and below we shall see the same claim with regard to the Hippocratic commentaries. Note further that within the preamble to the former work, $M M 1.1$ (X.1-2 K.), Galen laments the current intellectual climate and the likely fate - in terms of its reputation - of a work of intellectual value, thus at least implicitly and negatively acknowledging his ambition for his own works with a broader public.

21 For analysis of Galen's techniques of self-presentation see Boudon, V. (2000). 'Galien par lui-même: les traités bio-bibliographiques (De ordine librorum suorum et De libris propriis)', in Manetti, D. (ed.) Studi su Galeno: scienza, filosofia, retorica e filologia. Atti del seminario, Firenze, 13 novembre 1998, 119-33, as well as Boudon-Millot's 'Introduction générale' to Galien, Tome 1; Gleason, M. W. (1995). Making Men: Sophists and SelfPresentation in Ancient Rome; von Staden, H. (2009). 'Staging the Past, Staging Oneself: Galen on Hellenistic Exegetical Traditions', in Gill, C., Whitmarsh, T. and Wilkins, J. (eds), Galen and the World of Knowledge, 132-56; Boudon-Millot, V. 'Galen's Bios and Methodos: From Ways of Life to Path of Knowledge', in ibid., $175^{-89}$; more explicitly on such literary tropes in Galen, and their relatives elsewhere, König, J. (2009). 'Conventions of Prefatory 
Therapeutic Method were Hiero and Eugenianus, in the sense that the text was in some way formally presented to them, or that the Hippocratic commentaries were for the use of - or even in response to the requests of - students and friends, and were given to them in that context. The point is that such a dedication, or such a transaction, is made in the clear expectation that the works will be further circulated and, in at least some cases, with a reliance on this procedure for the dissemination of one's views and the development of one's reputation. The public reception, and criticism, of a work is being anticipated at precisely the same time that its original destination for an inner circle of students is asserted. A good example is the preface to Galen's commentary on the Hippocratic Epidemics vi. Here Galen simultaneously anticipates the criticisms of a wider audience who will be impatient with a long exposition which engages in detail with previous commentators, admits that he has compromised with such expectations in the composition of the work, and reasserts the fundamental nature and origin or the commentary as a work for his own hetairoi (he also seems to imply that the main concession that he is making to the wider public is the very writing of this preface which explains the situation; on this point see further below). ${ }^{22}$ Or consider, as a particularly striking example of the non-contradiction of private 'giving' and public dissemination, the magna opera De usu partium and De placitis Hippocratis et Platonis. These were, at least formally, written in response to the request of a patron, Flavius Boethus, not for ekdosis. The first book (at least) of the former, and the first six of the latter, were presented to him, as indeed were early drafts of Anatomical Procedures. ${ }^{23}$ But no serious student of Galen can doubt that is on precisely these works that Galen in fact built his early reputation in Rome. The

Self-Presentation in Galen's On the Order of My Own Books', in ibid., 35-58. See also Mattern, Rhetoric of Healing.

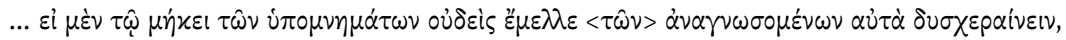

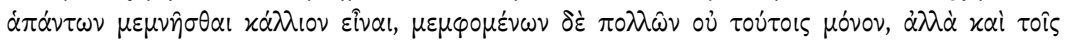

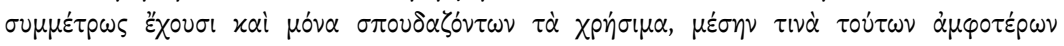

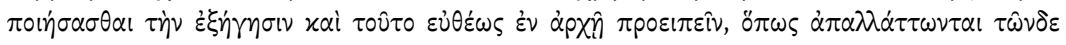

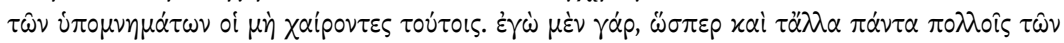

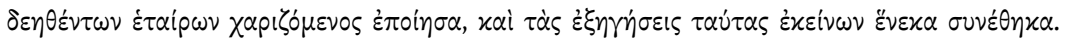

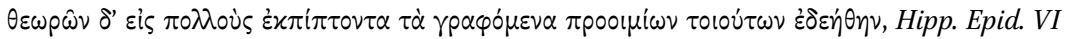
praef. (XVIIA.795 $-6 \mathrm{~K} .=4,19-5,3$ Wenkebach).

23 See Lib. Prop. 1 (XIX.15-16 K. = 139-40 Boudon-Millot); cf. AA 1.1 (II.215-17 K.), which also mentions a number of other anatomical works given to Boethus. Note also that the account in $A A$ clearly states that the entire seventeen books of $U P$ were sent to Boethus

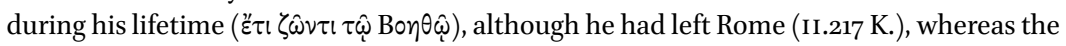
Lib. Prop. account speaks of one being written before his departure, but then is less clear about the process of the work's subsequent completion (with the above passage cf. Lib. Prop. 2, XIX.20 K. = 143,7-12 Boudon-Millot). 
further books, and further fortunes, of De usu partium are also highly relevant here: Galen speaks very clearly of the text's wide dissemination and influence amongst doctors, and again it was clearly a major work in the formation of his reputation. He does not, however, ever state (pace Vegetti) that he wrote or rewrote it for ekdosis.

A further complication should be considered here, which is the relationship of written-up accounts to public lectures or demonstrations. Galen does not deny the competitive and public nature of his activities in this area, especially in the field of anatomy: indeed, he gives us a very clear picture of the social and intellectual climate within which this persuasive and rhetorical activity takes place; he also claims to have ceased such activity at a particular historical moment. In many cases, the texts we have are prefaced as being the written version of such public lecturing. The anatomical works just mentioned are one such example; The Therapeutic Method and De locis affectis are also so presented; so too is the short philosophical work Affections and Errors of the Soul. But we note, again, that such prefaces describe this writing-up as being for particular individuals, or for hetairoi more generally, even though the original oral context may have been a more public one. There is potentially a complex dynamic in play here: it may indeed be true, for example, that a work like De locis affectis, or even The Therapeutic Method, can best be read, not as a stand-alone text but in conjunction with the oral exposition of which it claims to be a record or reminder. Still, the same point already made will apply: the writing-up, though officially defined as being for an individual, is a way of putting the work in the (or at least some) public domain, of ensuring a further dissemination, even if we have no way of being specific about the extent or precise nature of that dissemination.

But we should return to chapter 9 [6] of My Own Books and read a little further, because it is here at last that we get, apparently, a positive mention of Galen's own role in ekdosis (all the other mentions in My Own Books were denials). It is in fact the only place in Galen's work - before the discovery of $\pi \varepsilon p i$ $\dot{\alpha} \lambda u \pi i a s$, that is - where we get such a positive admission; it will therefore be important to consider what is actually being stated here.

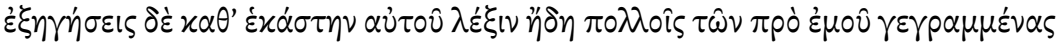

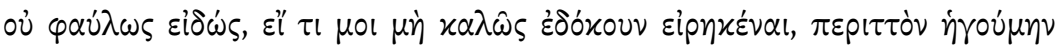

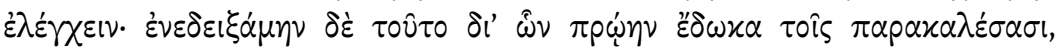

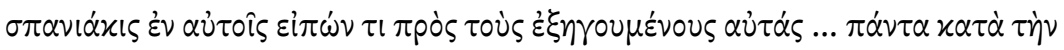

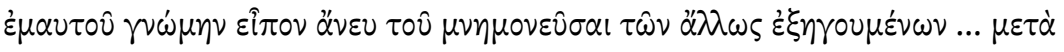

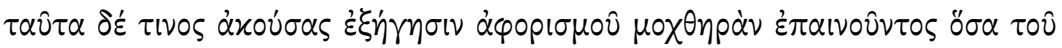




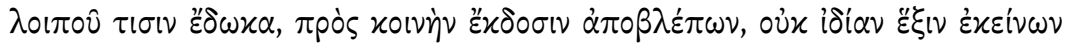

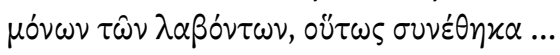

Line-by-line commentaries had already been written by many before me, which I knew perfectly well; and I considered it superfluous to refute anything in those which appeared to me incorrect; I had indicated this previously in what I gave to those who made requests to me, where I seldom made reference to other commentators ... I stated everything in accordance with my own opinion, without mention of those who gave other interpretations ... but after this I heard someone praising a bad interpretation of one of the aphorisms, and then whatever I gave to people I composed with an eye to general distribution, not to the level of those people alone who were the recipients ...

Lib. Prop. 9 [6] (XIX.34-5 K. = 160,1-21 Boudon-Millot)

This, then, is the passage that has led to the clear distinction, in modern scholarship, between two actually distinct categories of Galenic commentaries on Hippocrates: the first, intended for limited circulation, and not engaging with the commentaries of others, the second for a wider public and engaging in such argument. ${ }^{24}$ But again, let us consider what Galen actually says. The phrase on which this intention to publish, or to engage in wider distribution,

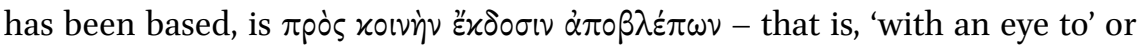
'with consideration of' a more general distribution. And it must be taken with

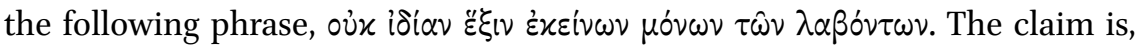
still, that there is a specific group of individuals (Galen's own followers; see further below) who are the works' actual recipients; it is just that in writing works for them, after a certain point, Galen takes into account that they will, as a matter of fact, reach a wider audience. This is entirely consistent with the picture that emerges throughout this book and elsewhere - the picture, indeed, which Galen wishes to give us - that he is writing for individuals, and that $e k d o s i s$ is something that he is aware will happen, not something which

24 The classic work on Galen's Hippocratic commentary activity (and classic statement of this distinction) is Manetti, D. and Roselli, A. (1994). 'Galeno commentatore di Ippocrate', in $A N R W$ II.37.2, 1529-1635. But see von Staden, 'Staging the Past', 140-50, who while in broad terms accepting the private-public distinction, also draws attention to a number of specific ways in which such a distinction is not borne out - at least not straightforwardly by the actual content of the texts. This seems to me extremely significant: the clear division of Galen's commentaries into two categories is frequently stated, while detailed analysis of the commentaries themselves is a much less common enterprise. 
he initiates. In this text, he is indeed admitting that in the composition of the later Hippocratic commentaries he 'had an eye' to ekdosis. He does not claim to have carried out the ekdosis, nor does he give us any information about the broader group that this, as opposed to earlier commentaries, was intended to reach. Certainly, the reason for the reference to ekdosis is (at least implicitly) that he believes that his works can be of some public benefit: they can refute errors which are current because of other people's Hippocratic commentaries. But he has stopped short of admitting his own role in self-distribution.

But there is much stronger evidence for Galen's own account of his own distribution - or rather non-distribution - of his works, specifically in the more detailed account of the genesis and progress of his Hippocratic commentaries given in his commentary on Epidemics III; let us therefore now turn aside from the rather summary, we might say flitting, account of My Own Books - an account which is, as we have seen, not devoid of both interpretive and textual difficulties - to that more detailed and informative one. What is in fact stated, very clearly, in this longer version is that all Galen's commentaries were written in response to individual requests, in particular those of his hetairoi. If the account of the genesis of the commentaries in My Own Books has three stages - those treatises which covered Hippocrates' thought and so were quasi-commentaries; line-by-line commentaries written in response to requests; commentaries responding directly to other commentaries - then that in the commentary to Epidemics III has fully seven, each presented as a response to requests, either of hetairoi or of a wider group. ${ }^{25}$ First (i), we have the stage of writing nothing except at the request of hetairoi who want notes of previous oral instruction; then (ii), the writing of works on 'all parts' of medicine, in response to the fact that these previous works have been distributed more widely and found useful by others too. Next comes (iii) the writing of specific works on Hippocrates in response to hetairoi, which is followed by (iv) the writing of commentaries on Regimen in Acute Diseases and Humours in response to specific, urgent requests, (v) the urgings of both hetairoi and other friendly doctors to write commentaries on all Hippocrates' works and (vi) a begging request to write a commentary on Prorrhetic. This was a pressing need because of the problems that arise from failure to understand the status and limitations of that work - an enterprise which in the process leads to the refutation of false exegetes. Related to this last point, there then came (vii) the urgings of hetairoi which caused Galen, in moving from the commentary on Epidemics II to that on Epidemics III, to address false interpretations so precisely that a whole book of the commentary is dedicated to three case-histories.

Hipp. Epid. III 2, praef. (XVIIA.576-84 K. = 6o-66 Wenkebach). 
The account seems almost self-parodic in its repetition and elaboration of the theme of the reluctant writer, giving way by stages to the importunings of his followers and of other interested persons. But the essential point is that here, once again - and as typically throughout the Galenic corpus - it is personal requests that have been responsible for every fresh development - and in particular every new prolixity - in Galen's writings. Note in particular that the very last phase of this progress - part of the public distribution project according to the traditional view - is here again a phase carried out at the request of Galen's own hetairoi. Now, it is true that Galen is here indeed describing a relationship between the author and his intended audiences; but it is undeniable, also, that any reference to some larger group, as opposed to the close circle of his own hetairoi, is extremely limited. Certainly nothing as straightforward as an opposition between works 'for ekdosis' and 'not for ekdosis' emerges from this text. Most strikingly of all - and crucially for our understanding of what is going on here - it is Galen's response to individual, private requests which are, time and again, presented as the occasion for his most prolific literary outputs as well as those which would on other grounds have the strongest claim to be seen as 'for distribution' (The Therapeutic Method, De placitis Hippocratis et Platonis, ${ }^{26}$ the later Hippocratic commentaries).

We have seen, then, that Galen in My Own Books does not identify a category of books 'for ekdosis' contrasted with another, 'not for ekdosis'; and we have seen, further, that he has a consistent policy of denying or concealing his own role in ekdosis. He does not with any clarity identify two audiences, a closer and a wider group; ${ }^{27}$ he admits to writing works only (or almost only) at the request of friends, patrons or students; he writes and gives works - including and especially those with the largest public impact - for and to those persons; either as a result of that or through some other clandestine activities they end up in the hands of 'many'; it is also clear that this wider distribution - whatever his protests - is something that he expects to happen.

\section{$3 \quad$ Ekdosis and Galen's Oeuvre: the New Evidence of $\pi \varepsilon p i \dot{\alpha} \lambda \nu \pi i a s$}

The text of $\pi \varepsilon p i$ à $\lambda v \pi i a \varsigma$ contains some striking new information on Galen's attitude to ekdosis. Before turning to that, let us conclude our survey of Galen's

26 See PHP 7.1 (v.586-7 K. = 428,4-17 De Lacy) for its own internal account of its composition - in a very public, competitive context - in response to the urgings of his own hetairoi.

27 But on this point see further below. 


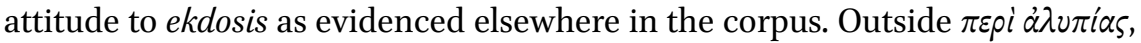
the term is in fact used by Galen between twenty-six and twenty-eight times (depending on textual readings in Lib. Prop.). In six of the instances, he is using the term in the specific sense of a particular edition of a previous author's work - the author in question being usually Hippocrates. ${ }^{28}$ There is then a usage whereby Galen refers to an author's ekdosis - or non-ekdosis - of his own works. One such case involves a philosopher producing a 'second ekdosis' of his book in response to criticism; ${ }^{29}$ but by far the most frequent use is to refer to Hippocrates' attitude to his own works, in particular the different books of Epidemics. ${ }^{30}$ Here Galen is justifying the interpretive approach that he has towards Epidemics I and III, on the one hand, and Epidemics II and VI, on the other. The backward projection by Galen on to Hippocrates of his own attitudes and compositional practices is in itself interesting. It is noteworthy, here, that although Galen does attribute some kind of ekdosis activity to Hippocrates, here too the preponderance of the references is in the negative: the fact that works were not for ekdosis explains their incomplete or elliptical nature. Finally, we have the four (five if we follow Müller's reading for the ch. 9 [6] text) cases which we have already considered in My Own Books, to which we may add one instance in Anatomical Procedures - again, a general denial that his works were written pros ekdosin. ${ }^{31}$ It is also worth noting that in only two of all these cases is the phrase pros ekdosin coupled with an article, e.g. tois

28 The 'Attican' edition of Plato (In Plat. Tim. frag. 2); Artemidorus Capito's edition of Hippocrates (HNH 1.2, XV.21 K. = 13,19-20 Mewaldt); that of Bacchius (Hipp. Epid. III 2.8, XVIIA.619 K. = 87,11 Wenkebach); Dioscorides' edition of Hippocrates (Hipp. Epid. III 3.74, XVIIA.732 K. = 158,8-9 Wenkebach; ibid. 1.18, XVIIA.559 K. = 47,2 Wenkebach; cf. Hipp. Off. Med. 1 praef. хуıнв.631 K.).

29 De marcore 2 (VII.670 K.).

30 Epidemics II and VI were not for ekdosis, as were books I and III: Hipp. Epid. III 3.1 (XVIIA.648 K. = 109,8-10 Wenkebach); similarly: Hipp. Epid. VI 1 praef. (XVIIA.796 K. = 5,4-7 Wenkebach); ibid. 2.15 (XVIIA.922 K. = 75,25 and 76,4-5 Wenkebach); ibid. 2.46 (XVIIA.1001 K. = 118,24-5 Wenkebach); ibid. 3.3 (XVIIB.12-13 K. = 130,12-14 Wenkebach); ibid. 3.17 (XVIIB.52 K. = 151,9 Wenkebach); ibid. 4.11 (XVIIB.153 K. = 208,2 Wenkebach); ibid. 4.20 (ХVIIв.183 K. = 227,28 Wenkebach); ibid. 5.3 (ХVIIв.241 K. = 264,14 Wenkebach); similarly (only the first and the third were written hōs pros ekdosin): Hipp. Art., XVIIIA.530 K.; cf. Hipp. Off. Med. 2.26 (хvin в.79o K.; ibid. 3,29, хvinı.879 K.).

$31 \quad A A$ 1.1 (II.217 K.) There is one further possible case in Lib. Prop., though it has been deleted by both modern editors. In ch. 16 [13], in his account of Platonic works, the reference to Quod animi mores in both Greek Mss (but not in the Arabic) contains the phrase: $\beta^{\prime} \cdot$ xai

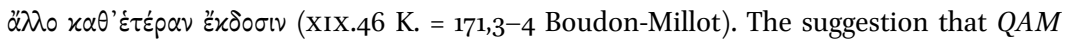
had a two-book version, or indeed that it circulated in two versions, is intriguing, though unsupported by other evidence. It is, however, worth remarking that if this phrase were genuine, it would constitute the only explicit reference by Galen, using this terminology, to two different ekdoseis of his own works. 
pros ekdosin, thus indicating a distinct category of works so intended; and both these cases refer to Hippocrates, not to Galen himself.. ${ }^{32}$ That is, in no case before the discovery of the $\pi \varepsilon p i$ à $\lambda u \pi i a \varsigma$ - does Galen use the phrase ta pros ekdosin, 'works for distribution', in relation to any category of his own work.

Which makes the material in $\pi \varepsilon p i$ à $\lambda v \pi i a \varsigma$ all the more interesting. For here Galen does indeed use precisely such an expression. The uniqueness, within the Galenic corpus, of both that formulation and the information contained in it, has not, I think, been properly noticed. It will, then, be of some importance to understand what is actually being stated here.

The crucial passage, which follows on from the mention of his work on Old Comedy, is as follows:

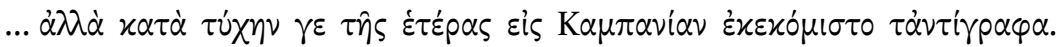

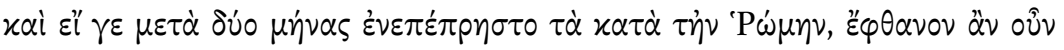

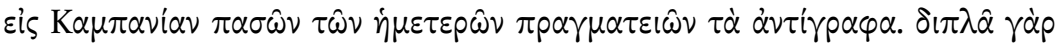

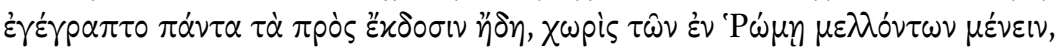

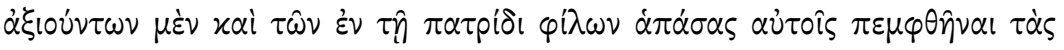

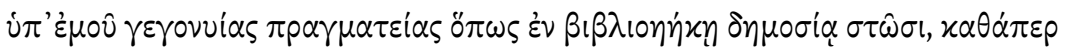

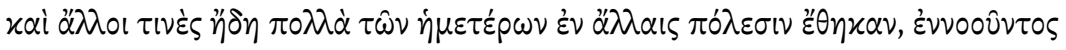

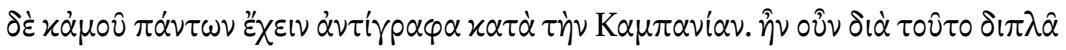

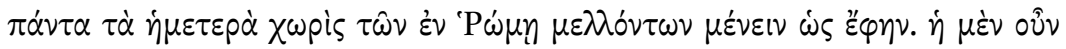

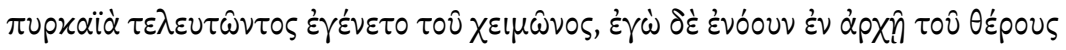

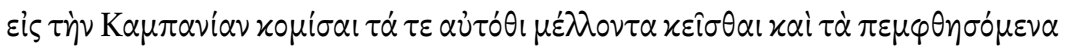

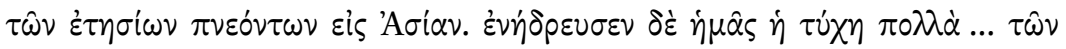
$\dot{\eta} \mu \varepsilon \tau \varepsilon \dot{\varepsilon} \rho \nu \nu \alpha \dot{\varphi} \varepsilon \lambda_{0} \mu \varepsilon \dot{\varepsilon} \eta \eta \beta i \beta \lambda i \omega \nu . .$.

... but by chance the copies of the second [sc. part of my work on Attic terms] had already been transported to Campania. And if the buildings destroyed by fire at Rome had been destroyed two months later, by then there would already have been copies of all our treatises in Campania. For all those for distribution had already been written in two copies, apart from those which were to remain in Rome, since my friends in my homeland, too, asked for all the treatises produced by me to be sent to them so that they might be put in a public library, in the same way that certain others, in other cities, had already deposited many of our works, and I, too, planned to have copies of them all in Campania. This, then,

32 At Hipp. Epid. vI 2.15 (XVIIA.922 K. = 75,25 Wenkebach) and Hipp. Off. Med. 3.29 (Xvin B. 879 $\mathrm{K}$.), though the latter is a reference to hypothetical work which might have been distributed to give the fuller account. 
is why all our works had been done in two copies, apart from those that were to remain in Rome, as I said. Now, the fire happened towards the end of winter, whereas I planned that at the beginning of the summer I would send to Campania both those works that were to stay there and those that would be sent to Asia once the Etesian winds had started. But chance waylaid me, taking away many ... of our books ...

Ind. $20-23 \mathrm{~b}(8,15-9,13 \mathrm{BJP})^{33}$

Three phrases here seem to me particularly worthy of note, and of analysis. First, the expression panta ta pros ekdosin. In the light of our previous survey, we now see that this is an almost unique case of Galen acknowledging (at least implicitly) his own role in an ekdosis process of his own works, and a completely unique case of his use of the phrase pros ekdosin with the article, again in relation to his own (rather than Hippocrates') works - thus denoting a specific category of works so intended. To which works is Galen so referring, and what is the nature of the ekdosis in question? We must also simultaneously deal with a related problem of interpretation: what is meant by chōris tōn en Rōmèi mellontōn menein $(8,20-21 \mathrm{BJP})$ ? Thirdly, what is the reference of panta ta hèmetera (9,6 вJP)?

To take the last phrase first: we noted above, in the passage from ch. 14 [11] of My Own Books, that the similar formulation, talla ta hèmetera, seems to refer to a category implicitly separate from the 'private' one for his own exercise (some of which were also informally circulated). The fact that the phrase here clearly functions as the equivalent of panta ta pros ekdosin - it substitutes for that earlier phrase in a recapitulation of the identical information a few lines later - strengthens that interpretation. Both phrases, it seems, may be taken to refer to some formal, 'official' group of Galen's own works. Although (as already remarked), Galen's choice of nouns in reference to his own writings is notoriously fluid, this group seems - in the present passage at least - also to be coextensive with pragmateiai, treatises. Thus, it seems, at least on a fairly natural reading of the present passage, that Galen is here - in apparent contradiction of the picture that I have been painting - suggesting a distinct list of those works which constituted his public output: works for ekdosis. This set, he further suggests, would be preserved both by his making of a 'backup' copy for his

33 My translation. Note that I have used one-to-one correspondences to reflect the distinction between terms used by Galen in each of the references to his own works (even if the distinction of terms may not in fact correspond to a significant conceptual distinction): 'treatise' renders pragmateia, 'book' renders biblion and 'works' is used where Galen simply has a neuter plural adjective without noun. (See further below on the significance (or not) of the use of the term hupomnemata for certain works.). 
house in Campania and by their being deposited in public libraries. This, then, seems also to make natural sense of the phrase chōris tōn en Rōmèi mellontōn menein, which in itself might admit of a number of interpretations. The official catalogue of his oeuvre, Galen is (on this interpretation) suggesting, exists in a single copy deposited in his storehouse in Rome, to which further copies may be added, to be held elsewhere. ${ }^{34}$

This new picture, then, of the official oeuvre which is both deposited in the storehouse and simultaneously pros ekdosin, reminds us rather strikingly of the passage which we have already considered from De compositione medicamentorum per genera. There, we saw, there is an explicit pairing of precisely these two concepts: 'having been distributed and deposited in the apothēke'

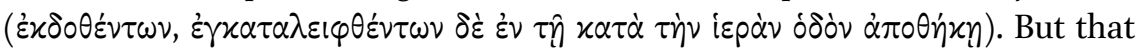
passage, in conjunction with the present one and other usages which we have seen, suggests another important dimension of ekdosis and its cognates, namely that what is referred to in these terms is not, or not only or primarily, a process of distribution, but includes crucially the notions of editing, writing-up or completion of a pre-existing text.

This, of course, is quite consistent with the process which previous scholars have identified: works previously existing in note or outline form (for private use or informal circulation) are written up for $e k d o s i s$ for a wider audience. ${ }^{35}$ But two crucial points need to be made in qualification of such a picture. The first is that - as we have already seen - such a formal list of 'public' works will, in fact, include works which Galen explicitly describes as having been written for his own hetairoi; in fact, it seems impossible - at least as far as Galen's main medical output, including the Hippocratic commentaries, is concerned - to identify any works in the 'public' list which are not officially so intended. The second, related, point is that what is at stake in the 'private-public' distinction is then a difference in editions of the same work, not a distinction between different works.

34 The interpretation is consistent with the translation of BJP ('... tous mes livres qui étaient destinés à la publication ... sans compter les exemplaires qui devaient rester'), i.e. there are three copies in all. A more literal grammatical reading would want chōris, etc. to be an exclusion clause, so referring to a subset of those for distribution, i.e. 'all those for ekdosis had been written in two copies, except for those which were to remain in Rome [which had not been so copied]'; the chöris clause would thus introduce a new category. One might in that case further suppose that the choris phrase is applied rather loosely, and what is meant is not 'all works for ekdosis had been copied, except for those for Rome ...' but 'all works for ekdosis had been copied, except that some [not for ekdosis], which were for Rome, had not been copied'. On balance, our first interpretation seems both the most natural and that which will best assist us with the categories of works which then follow.

See the literature already cited in n. 8, especially the discussions of Dorandi. 
In this context, we should consider also the other two occurrences of the word ekdosis in $\pi$ epi à $\lambda v \pi i a s$. One clearly falls in the category of scholarly 'edition' or 'version', which, as we already saw, is a common usage, especially in relation to commentators on Hippocrates; the interesting variation here is that it is Galen himself who has produced an ekdosis of another author. ${ }^{36}$ The other

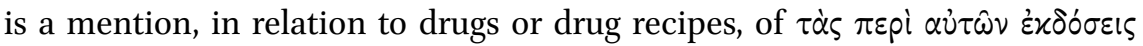
reyovvias (Ind. 5ob, 16,13-14 BJP); here Galen is referring to his own compositions; and the context, which is that of a recapitulation of items already mentioned, makes it clear - consistently with what we have just observed - that the term ekdoseis here corresponds to what was earlier referred to (at 37, 12,22-3 $\mathrm{BJP}$ ) as a pragmateia. The work in question is, in fact, that on the composition of drugs, already discussed. The term ekdoseis here can, indeed, be seen as related to the reference which we saw to that work as ekdothenta (a reference which, as we also saw, is for Galen quite consistent with the claim that it was written for hetairoi). But this interpretation, or focus on the sense of ekdosis as referring to an editorial process or version, raises further problems. In principle, the notion of a later, more formal, writing-up of works which had previously circulated in a smaller circle, seems an eminently plausible one. Yet, as has been pointed out by others, ${ }^{37}$ Galen very seldom in fact acknowledges that he has produced more than one version of the same work. If he had done so, one might, indeed, expect that more than one version of the same work would be in circulation. Galen does, indeed, acknowledge the problem of the circulation of faulty, or superseded, versions of his writings; but this seems to be a problem confined to an early phase of his writing, and one which he regards as largely resolved early on in his career. ${ }^{38}$ If more than one version - an earlier, informal one and a later, official one - of a range of his mature works were in circulation, one would surely expect some discussion by Galen of the problems that would inevitably ensue. In one case, that of $A A$, where Galen does explicitly state that he wrote a subsequent version of an earlier text (see n. 23 above), the overdetermined nature of his explanation seems revealing. That is, while he claims that the earlier - not-for-ekdosis - version is lost, he gives an additional reason for rewriting, namely that he had acquired more accurate anatomical knowledge.

Crucially, indeed, Galen does not describe processes of rewriting or revision of the same text, but rather - precisely to the contrary - uses his original

$36 \quad$ Ind. 14 (6,11 ВJP).

37 See Gurd, 'Galen on है $x \delta$

38 The phenomenon of books of his own composition in need of correction being returned to him, after his first visit to Rome, is discussed in ch. 2 of Lib. Prop. 
authorial intent as an explanation of the content of the final version of the text which is in the public domain. We have seen, for example, how the changing demands and requests of his own hetairoi are used to provide an account of the process of development of his own Hippocratic output: those individual demands and requests, that is, explain the content of the last commentaries those which were written 'with an eye to wider ekdosis' and are 'works for publication' if any are. What, then, can be made of the process of 'editing' which I have suggested gives at least a partial account of what is meant by pros ekdosin in this passage from $\pi \varepsilon p i \dot{\alpha} \lambda v \pi i a s$ ? What, if anything, would be the substantial difference between a pros ekdosin version and the original which has circulated informally? As has been noted, the accounts of his own works in My Own Books and elsewhere represent a retrospective creation by Galen of an oeuvre, the establishment of a curriculum and canon of his own works by an author who claims to have been reluctant to put any of them in the public domain in the first place. ${ }^{39}$ But this process or organization and canonization involves not just the listing and categorization of his works in these autobibliographical books. There are also - as very clearly seen above, in the example of Hipp. Epid. $I I I$ - explanatory, apologetic and orientating remarks within the texts themselves, especially in their prefaces. Consider the preface to the first book of the commentary on Hippocrates' Epidemics VI.

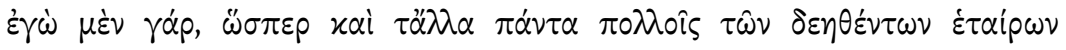

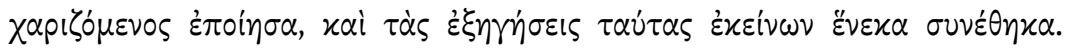

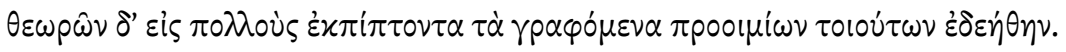

Just as I composed all the rest for the benefit of many of my followers, who had asked for them, I put together these commentaries for their sake too. But observing that what was being written fell into the hands of many, I needed such prefaces.

Hipp. Epid. VI 1, praef. (XVIIA.795-6 K. = 4,25-5,3 Wenkebach)

The passage incidentally gives yet another affirmation of Galen's claim - which we have now seen many times - to have written all such works for his followers. Our main concern here, however, is with the reference to prefaces. Of course, a preface containing such information on the previous history of the text is, by its very presence, an explicit acknowledgement that this version - the ekdosis, if one will - is not identical with that which has previously circulated. By the

39 The point is well made by Boudon-Millot, 'Galien par lui-même'; cf. also Vegetti, Nuovi scritti. 
same token, however, and as we saw very clearly in the example of Hipp. Epid. $I I I$, it functions as an apologetic for the extent to which the two forms of the text are the same.

Could it be that to produce the ekdosis of a previously circulated work consists in little more than in adding a preface to it? Such framing - such selfpositioning - is, as we have seen, of enormous importance to Galen. There would, doubtless, be other processes involved: checking and correction, perhaps the writing eis katharon edaphos, the production of a clean copy which, again in the context of editions of other authors, is mentioned elsewhere in $\pi \varepsilon p i \dot{\alpha} \lambda u \pi i a s^{40}$ But the fact that such apologetics as are found in the prefaces speak to the substantial identity of the previous, circulated version with the final, written-up article is highly significant, though easily ignored. A work may - as indeed Galen essentially claims for his works in general - have not originally been intended for ekdosis (and of course how seriously one takes that claim may be a matter of individual interpretation); but in principle any work, whatever its origin, could end up in the pros ekdosin list; and that destiny, one might suppose (though we will return to this question in due course), may correspond also to its ultimate inclusion in the list in My Own Books.

We should proceed to enquire what - in the specific context of the passa-

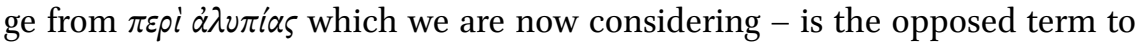
the panta ta pros ekdosin category. Before doing so, we should consider a little more closely what else this particular passage is telling us about ekdosis. For in the immediately preceding paragraphs I have focussed on ekdosis as process of edition; but our passage tells us something about ekdosis as process of distribution, too. Here, let us again emphasize the point: this is by far the clearest account Galen gives us of his own role in the ekdosis of his own works; it is a unique admission in the corpus. His clearest account, however, is still very far from clear. He does not tell us either which works the panta ta pros ekdosin were, nor what was involved in the process of preparation or editing; and we have to engage in an intricate, not to say speculative, process of analysis to arrive at the answer to this. And the context of Galen's admission of his own ekdosis activity is surely relevant here: he is making as vivid as possible the account of his own losses, and he can hardly do that without mentioning the full extent of the texts that were lost. It is only in such a rhetorical context that Galen has allowed himself to be forced into the admission - still reluctantly, and of course only in the passive voice - that he had works of his own copied for distribution. The loss of these copies - so soon before they would have been safe - makes the events all the more dramatic. Moreover, and still consistently 
with what we saw above, where Galen only explicitly admits that he intended to give books to friends, rather than giving them out to a public - the only actual process of ekdosis he admits as his own remains that of giving his works to friends back home, at their request. (It happens that they have made this request because they want the works to exist in a public library - but such a provision is, of course, their act and not his.)

One final point on the actual ekdosis process. It seems possible, as already suggested, that the term panta ta pros ekdosin does indeed correspond to Galen's 'back-catalogue' - to the set of his works which he regards as his canon, and which have been written up at a certain level, so that they may be consulted by others. The peculiar historical accident and atrocious timing to which Galen refers, however, require a little more attention. If Galen indeed had such a central repository of his own writings in his storehouse in Rome, then the destruction of the whole collection in the fire was indeed a monumental loss. It is, as I have already suggested, remarkable in this context that Galen makes so little of it, in terms of the extent of his own works lost, focussing rather on a couple of his own works and devoting more attention to editions of other authors, not to mention drug collections and other valuables. That focus is, as I have also suggested, explicable precisely in terms of the actual networks of distribution that functioned in relation to a successful author's work: put simply, he could be confident that the vast majority of his works were, in fact, extant in other collections.

But there is another detail worth considering here. Granted that Galen may have had such a comprehensive collection of his own writings in their pros ekdosin form, is it plausible that he had just now, at this precise historical moment, had two further copies made, of the entire set? If one pauses for a moment to consider the situation, one soon realizes that such a possibility would, indeed, beggar belief, from three points of view. First, the coincidence in that case - the fire came at the precise point when Galen had just decided to make two additional copies of all his works, constituting his lifetime's oeuvre, and take them out of Rome, for distribution and safe-keeping - would be truly staggering; secondly, this would imply that Galen had just made a decision, in his mid-sixties, radically to change his longstanding practices in relation to $e k d o-$ sis, both producing a back-up and instigating a particular form of distribution to libraries via friends in Pergamum - never previously contemplated; thirdly, the copying, twice, of his entire output - even if we take that output by 192 to have run to only about three-quarters of its final extent (a very conservative estimate) - would have entailed the writing of about seven-and-a-half million words by his scribes in a single phase. If the accident of timing had involved such a truly massive loss, Galen would surely have made more of it than the 
few phrases contained in the passage above; as for the second hypothesis, that Galen has suddenly now revolutionized the distribution practices of a lifetime, that is something that could hardly have been passed over without discussion: indeed, it would mean that the ekdosis referred to here was, in a sense, a completely new project. And as for the seven-and-a-half million words - such an undertaking, even by the standards of Galen's undoubtedly hard-worked teams of scribes, would have been more than prodigious.

A far more plausible interpretation of what Galen means, I submit, is that two copies had been made of those works which were intended for $e k d o s i s$ at this particular time. The reference to sending works to Asia once the weather turns is, surely, a reference to a regular, very probably yearly, practice; Galen's friends back home (even if one takes this story at face value) have not, on any plausible account, suddenly requested his whole oeuvre; and the notion that a successful author, conscious of his reputation and keen to secure his Nachleben, would, on a regular basis, in batches, both make a backup copy and send his works to libraries in Asia, is a wholly reasonable and likely one. Such a process, again, helps explain Galen's - in the circumstances - comparatively relaxed attitude to the losses: previous batches of work, once they reached the pros ekdosin state, have already been sent to Asia (and possibly also to the house in Campania); it is only the latest batch which causes concern. And that, indeed, is precisely why the only two mentioned by name are the commentary on Old Comedy - just written - and the work on the composition of drugs apparently written earlier, but by whatever quirk of fate not extant (or at least not locatable in Rome). We thus have, in conclusion, two distinct, but I suggest complementary, interpretations of the phrase pros ekdosin in this particular passage, referring both to a phase of completion or edited form, and to an intention to initiate wider circulation of works which have reached this form.

Pros Ekdosin; Hupomnēmata and Notes; Non-Surviving Works

I turn, then, finally, to the identity of the 'other' implied by the term ta pros ekdosin in this passage, and to the distinctions made between different types or levels of work, amongst those lost in the fire. For we do here get discussion of something like a 'private' category, and an attempt to identify it will be of some value to our enquiry.

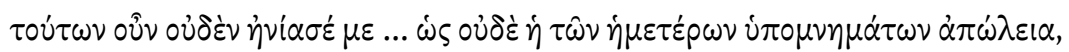

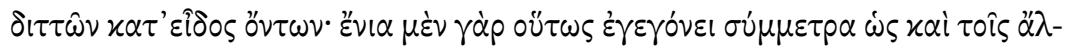

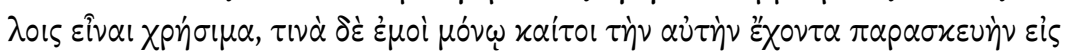




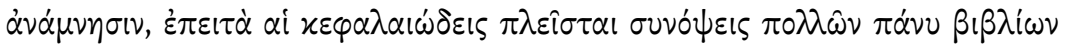

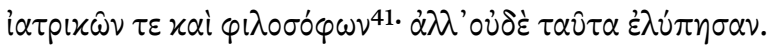

None of these things, then, grieved me ... nor did the loss of my notes, which were of two kinds: some had been produced in such a well-balanced way as to be useful to others, too, while others, although they had the same form of preparation as those, for reminding, were for myself alone; then there was the very large number of summaries by main heading, of an extensive list of medical and philosophical books.

Ind. 29-30 (10,24-11,7 BJP)

The passage comes at the climax of the account of the loss of his books, just after the discussion of his work on words in Old Comedy. The term hupomnèmata here seems to introduce a fresh category - although at some distance in the text - in addition to the pros ekdosin works and pragmatei$a i$ already mentioned. ${ }^{42}$ For that reason, as well as to point up the relationship between this characterization of works and the term 'for reminding', zis $\alpha \nu \alpha \mu \nu \eta \sigma v$, I have here used the admittedly not unproblematic translation 'notes', rather than the more neutral 'writings' or 'works'. It should be understood that the term hupomnemata, although it has an etymological and indeed apparently, for Galen, a conceptual relationship with the idea of notes, of an original oral context or of usefulness for delivering lectures, is used by him with a very broad and fluid application, and no clear distinction can be made consistently across his works between his use and application of this term and that of the terms 'treatises' (pragmateiai), 'compositions' (sungrammata) or 'books' (biblia). ${ }^{43}$ It seems, however, that in this context we here have a counterpart to ta pros ekdosin.

The hupomnèmata themselves are immediately subdivided into two kinds produced in such a well-balanced way as to be useful to others, and for himself alone; and then there is added a further, definitely private, category of

41 Although the form seems odd here, and вJP emend to $\varphi$ i $\lambda \circ \sigma \circ \varphi(x \omega \hat{\omega}$, I print the phrase in this form because of the identical pairing of adjectives at both Praen. 9 (xIv.650 K. = 120,1 Nutton) and Lib. Prop. 3 (XIX.19 = 143,2 Boudon-Millot): it seems that Galen may use

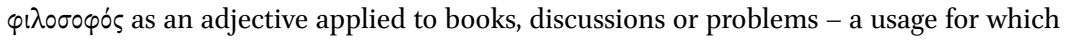
there is perfectly good precedent, e.g. Plato, Phaedrus $257 \mathrm{~b}$.

It is also a possible, in view of Galen's fluidity of use of the term hupomnēmata, already noted, as well as his frequently repetitive manner in this text, that he is here simply giving another recapitulation of the works already lost (cf. 20-23b), with slightly different terminology; but the parallels which we shall see with the similar passage about hupomnēmata in Lib. Prop. speak against this.

On this point see $n$. 11 above. 
'summaries by main heading' of works of doctors and philosophers. ${ }^{44}$ But what precisely does Galen mean by hupomnēmata here? Some were just for his own use, some distributed, but none (implicitly) were intended for $e$ kdosis. The primary reference of hupomnemata may be similar to that of a group of lost and unidentified works in ch. 3 of My Own Books, namely commentarystyle notes on other authors or specific problems. Or, the reference here may be a broader one: hupomnemata are, quite simply, those works of his own composition which have not reached the pros ekdosin state. But I note that there are - if we take it that this whole passage is intended as in contradistinction to ta pros ekdosin - three categories identified: ta pros ekdosin; hupomnēmata which might be shared; purely private hupomnemmata (together with which we may group the purely private 'summaries'). It is indeed tempting to map this on to the passage from ch. 3 of My Own Books, which we have already considered, where the term was gumnazōn emauton rather than hupomnèmata, but where a similar three-way division seems to be in play; and we shall return to that passage shortly.

First, it is worth pointing out that some such 'private' categories of notes would, plausibly, have been the main victims of the fire, in terms of irrecoverable losses. Certainly, no such synopseis survive (with the apparent exception of a summary of Plato's Timaeus, extant in Arabic); on the other hand we would probably not expect them to: some kinds of scholarly writing are too note-like and ephemeral to be expected to survive, even without a fire. But this consideration leads us to our final two questions: (a) can one identify any specific extant, or indeed non-extant but listed, works of Galen's as belonging to this 'for himself' category? (b) does belonging to this private category give an explanation, at least in some cases, of the loss of a specific work of which we know the title? Let us return to the passage from My Own Books which, we have suggested, quite closely parallels this reference to lost hupomnēmata in sections 29 and 30 of Ind.

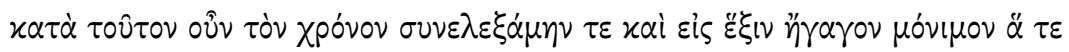

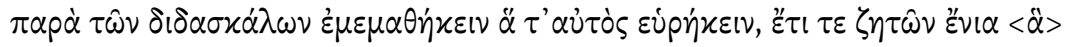

44 I have preferred the translation 'summaries by main heading', rather than 'chapter summaries', for kephalaiōdeis synopseis: certainly, the term kephalaion can mean chapter in Galen, but he also specifically mentions the scholarly or intellectual practice of collecting all an author says on a topic, and uses the term kephalaion in that context. Such sets of notes accumulating, with quotations and references, all an author says on a particular topic (rather than strictly linear chapter summaries) would then have constituted a valuable database to be drawn upon in the composition of one's own works. Cf. Ammonius, In Cat. 4, 3-13 Busse, where there is a description of note composition, including the term kephalaia. 


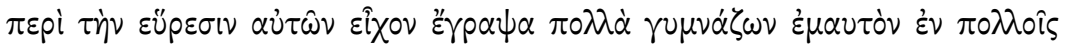

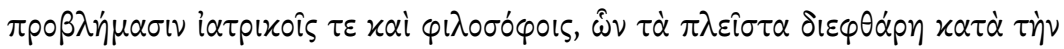

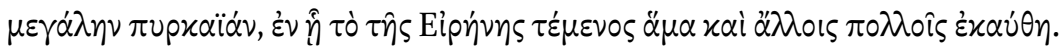

During this time, then, I collected together and brought into permanent form both what I had learned from my teachers and what I had discovered myself; I was also still engaged in research on some topics, and wrote down a lot that I had which was relevant to those enquiries, training myself in many medical and philosophical problems. But most of this material was lost in the great fire in which the Temple of Peace was consumed along with many other buildings.

Lib. Prop. 3 (XIX.19 K. = 142,25-143,4 Boudon-Millot)

Galen here makes a swift transition, from the first part of the sentence (up to

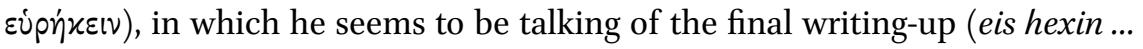
monimon), at a critical time in his career, of a core body of his works, to a category related to ongoing research and self-training (eti ... zêtōn ... gumnazōn emauton). ${ }^{45}$ Though the speed of the transition - from a clause summing up most of his core works to one referring to a whole different category of now lost ones - is confusing, it does seem clear that it is indeed the latter, 'ongoing research and private exercise' writings that are referred to as having been lost in the fire. There is another place where Galen mentions the losses in the fire a passage which we have already considered in a different context.

I also wrote a large number of other works as an exercise for myself; of these some were lost in the fire which consumed the Temple of Peace,

45 The period in question is $169-76$, to which, it seems, a majority of Galen's extant scientific and medical works may be dated (not including the bulk of the pharmacological works or most of the Hippocratic commentaries). Great caution must be exercised in assigning clear dates to Galenic works: there were clearly drafts and - as indeed the present text makes clear - subsequent writings-up, and in some cases later revised versions; it is also clear, simply from a consideration of the totality of cross-references between works, and the inconsistent chronological picture that emerges from them, that material can be added to texts at different phases. A useful overview of relative dates is nonetheless still that of Bardong, K. (1942). 'Beiträge zur Hippokrates- und Galenforschung', Nachrichten von der Akademie der Wissenschaften in Göttingen, Philologisch-Historische Klasse, Nr. $7,577-640$ (who is not insensitive to these complexities). He assigns 23 treatises to this period. See also Peterson, D. W. (1977). 'Observations on the Chronology of the Galenic Corpus', Bulletin of the History of Medicine 51, 484-95; and Boudon-Millot, Galien, Tome I, 'Introduction' and ad loc. 
others had been given to friends and are now extant in many private collections, as is the case with my other works.

Lib. Prop. 14 [11] (XIX.41 K. = 166,1-5 Boudon-Millot)

It is true that we have seen considerable fluidity, even unreliability, in Galen's use of the phrase gumnazōn emauton. But the context here may be informative. As we saw earlier, the discussion of 'personal-exercise' works here leads into a discussion of hupomnemata, and a long list of commentaries and works on individual philosophical problems. Broadly speaking, again, it seems that a similar category of note-like, private-use writings on individual philosophical texts or questions, is being referred to here and in Ind. 29-30, as discussed above. But we are left with the following puzzle. In the later course of ch. 14 [11] of My Own Books Galen goes on to list literally dozens of such works on individual texts and questions in the area of logic and demonstration. ${ }^{46}$ If these correspond to the large group of gumnazōn emauton and hupomnēmata works which, Galen says, were lost in the fire, that would give us an at least partial answer to our initial question, and a neat account of why so many works on these particular issues are lost to us. But are we to imagine that Galen is, in fact, listing works which he knows to be lost? The earlier passage, in ch. 3, seems at least to imply that he is refraining from listing works in that category (and this would be consistent, too, with the suggestion that he has omitted mention of Prognosis in My Own Books because he believed that work to be lost). If, on the other hand, he has made a decision to list his lost works too, it is odd, to say the least, that he lists them without mentioning whether they are extant or not.

If, on the other, most or all of these works are extant at the time of the writing of My Own Books, then we have to accept that a fairly vast number of works of Galen have been lost to us, but in a way which has nothing to do with the fire at the Temple of Peace. Of course, many works by ancient authors are lost, and one does not perhaps need any explanation for the partial nature of the transmission other than the central authority role that Galen came to have, in later antiquity and the middle ages, in medical curricula, as against his much less exalted role in logic or philosophy.

46 To these we may add some of those mentioned also in chs 16 [13], 17 [14] and 18 [15], with which, however, there is some overlap: those latter chapters list works under the headings Plato, Aristotle, the Stoics and thus (especially in the case of Plato) include works of broader philosophical interest; this chapter concentrates on works of a highly technical, logical bent. 
Still, returning to the former hypothesis, there are, I suppose, two possible explanations for the presence in My Own Books of a number of works which had already been lost at the date of that work's composition. One is that - as we have seen in other contexts - Galen may hope that someone else has a copy of a work, even if he does not. That possibility would, admittedly, be in literal contradiction with the characterization of the works as for his own use alone; on the other hand, we have already seen Galen committing this contradiction. Another explanation, however, may lie in a closer consideration of this very concept: the date of composition of My Own Books.

This text, it seems to me, is likely to have been composed provisionally as a list and added to over years. Even if works composed after the early $190 \mathrm{~s}$ are, in general, absent from it, and in that sense such a date is to be seen as that of its completion, it could still have undergone revision and updating at later times. It may be that the sentences mentioning the fire of 192 belong to such a later updating - an updating which nonetheless did not extend to the deletion of all references to works lost in the fire. Such non-deletion may seem odd; but the matter could be explained by some uncertainty - of a kind, I suppose, familiar to most scholars in relation to the organization of their most informal or private sets of notes - in Galen's own mind as to precisely what he still had, and where. At any rate, I think we may say that - if my account of My Own Books as a work which was composed over a period of time is correct - it is also possible that its revision was partial and incomplete. Or it may be that the vast body of works mentioned in ch. 14 [11] were indeed more 'note-like', sketchy and private in their use than others, and that this smaller circulation, or non-circulation, accounts for their loss - even though they were extant after the fire. On this interpretation, we are given no further information about the gumnazōn emauton category in which Galen claims to have lost so many books, and can in no way map it on to any existing list. We would also, on this view, have solved the problem of identifying a genuinely 'not for publication' category, within Galen's explicit list of his own works; but would still be left with the puzzle as to the precise identity of the gumnazōn emauton works which were lost (and it might also seem strange that this vast set of listed works, if they genuinely were for private use and not copied, did survive the fire). Some puzzles, certainly, remain; but I hope that the above has shown with greater clarity what we learn from $\pi \varepsilon p i$ 'ं $\lambda v \pi i a s$, taken in conjunction with Galen's 'autobibliographical' remarks elsewhere, about book composition and distribution in the GraecoRoman world, about Galen's own practices in particular, and about what can and cannot be deduced from what he himself says - or fails to say - about ekdosis. 
We should add, finally, that the above analysis should not be taken as denying that Galen does, indeed, intend certain of his works for different audiences, or that some such distinctions can be discovered. ${ }^{47}$ Rather, my claim is that such a distinction, within the extant works, cannot be mapped on to a theoretical one between works for ekdosis and works not for $e k d o s i s$ - a distinction which Galen does not in fact make in this form - and further that those works which we do possess are, typically, both not for ekdosis (in the sense that this is Galen's claim about his intention when writing them) and for ekdosis (in the sense that these same works are subsequently made available in an edition for distribution, with minimal if any differences between that ekdosis and the previous version, indeed with so complete an overlap between the original and the ekdosis that the author feels obliged to explain features of the final version on the basis of their original composition).

There are, however, other kinds of distinction in audience and intent, though these are seldom clear-cut. There is, to be sure, the distinct category of works for beginners. There are also works which can be understood, on the basis of what Galen himself says, as intended for a broader audience than the usual medical one consisting of his hetairoi. For example, Galen uses the phrase 'for all' to characterize his intention in writing De sanitate tuenda - a work which on other grounds too can be identified as aimed at a non-medical, or broader, readership. ${ }^{48}$ It is interesting to place this 'for all' alongside a similar formulation in My Own Doctrines, in relation to his shorter ethical writings: ethical philosophy, he says there, is something both useful and possible for all to train themselves in, and he in this context mentions his composition of two books on the subject (presumably Affections and Errors). ${ }^{49}$ These are available for all

47 In relation to this discussion see also the bibliography cited at n. 14 above.

48 'The function [I so translate here dunamis] of them [sc. the short works De optima corporis nostri constitutione, De bono habitu and De inaequali intemperie] is contained also in the work on Matters of Health, in which the different types of constitution of our body are stated for all ( $\pi \hat{\alpha} \sigma v)^{\prime}$, Ord. Lib. Prop. 2 (94,12-14 Boudon-Millot; n.b. not in the pre-Vlatadon text); within the work itself he makes the distinction that it is for philiatroi, people interested in or friendly to medicine, as opposed to The Therapeutic Method which is 'only

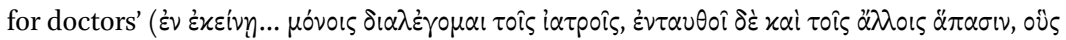

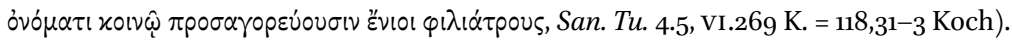

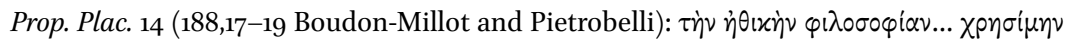

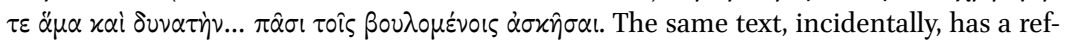
erence (if we trust the Greek Ms rather than the Arabo-Latin tradition) to De naturalibus facultatibus as having been written 'for all' - an interesting notion in relation to the following point about De placitis Hippocratis et Platonis and De usu partium and their 
to train towards virtue. And this may apply also to a range of other 'occasional' works on ethical and more popular themes (without their being extant, it is difficult to judge); indeed, the listing of such works in a series of separate chapters towards the end of My Own Books seems to highlight their separate status; certainly they stand outside the main curriculum of scientific, anatomical and medical works recommended for his students. And, as we have seen, there is a range of commentary-style works on specific philosophical texts and themes, mainly lost, which it seems that Galen does not intend for the majority of his readers, or even for the majority of his medical students, and which (although, as we have seen, certainty in these areas is impossible) probably never achieved a wide circulation.

There are also, of course, considerable variations, within the central list of Galen's work presented to us with an order for reading in My Own Books and The Order of My Own Books, as to how directly relevant they are to medical training or practice. Indeed, the latter work explicitly states two different possible starting-points, or courses, for readers, within that central list. The only substantial difference made explicit is whether one starts with the great work (also lost), De demonstratione, or omits this - that is to say, whether one's medical training or knowledge will be based on the understanding of what constitutes a logically secure demonstration, and on the ability to produce such. But apart from that explicit distinction, there are others. Galen does not himself present the sliding scale of the course, from more theoretical areas - element theory, physiology - to the more practical, clinical ones, as a difference based on audience; that is, he does not explicitly suggest that a more practically, less theoretically, inclined student should cut to a later point in the curriculum. On the other hand, there are certain works which clearly belong both to an early phase in Galen's clear and to the project of establishing his intellectual reputation, in anatomy and related theoretical areas, in a highly competitive and public context, amongst the intellectuals of Rome. We have seen that on both internal grounds and the basis of what Galen tells us about the circumstances leading to their composition, both De usu partium and De placitis Hippocratis et Platonis - or, to be more precise, these works in a certain phase of their composition - belong to that phase. These works are in that sense more 'public', and it is also true that their content, theoretical and scientific in nature - indeed, laying out the most central of Galen's views on the functioning and structure of the body - is less closely tied to medical usefulness.

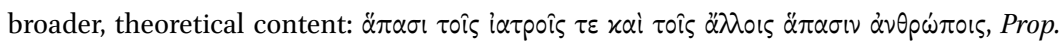
Plac. 3 (174,22-3 Boudon-Millot and Pietrobelli). 
On the other hand, such differences of original intent are occluded by Galen by the very fact of his listing, all together, of a central body of works in terms of suggested order of reading. This is, we have seen, a retrospective construction, which to a considerable extent tends to obscure those questions of original audience and argumentative context. And, as we have also seen, Galen repeatedly claims that his central body of works - including also the Hippocratic commentaries - is aimed at, and written at the request of, his hetairoi, students, people with serious medical interests. Dual intent runs throughout this corpus. The claim that works were written for this specific group - or even for one member of it - is, for Galen, in no way in contradiction with the ambition to gain for them a wide distribution which will both enhance his reputation and disseminate his views throughout the intellectual world.

\section{Acknowledgements}

The author gratefully acknowledges the financial support of the Wellcome Trust and the Alexander von Humboldt-Stiftung during the research and writing of this paper. Heartfelt thanks go also to the editor, Caroline Petit, for her invitation to participate in the conference from which this chapter arose, and especially for her very helpful advice and encouragement during its subsequent development. The faults which it retains are, of course, my own.

\section{References}

Bardong, K. 'Beiträge zur Hippokrates- und Galenforschung', Nachrichten von der Akademie der Wissenschaften in Göttingen, Philologisch-Historische Klasse, Nr. 7 (1942), 577-640.

Boudon, V. 'Galien par lui-même: les traités bio-bibliographiques (De ordine librorum suorum et De libris propriis)'. In Studi su Galeno: scienza, filosofia, retorica e filologia. Atti del seminario, Firenze, 13 novembre 1998, ed. D. Manetti, 119-33. Florence, 2000.

Boudon-Millot, V. 'Un traité perdu de Galien miraculeusement retrouvé, le Sur l'inutilité de se chargriner: texte grec et traduction française'. In La science médicale antique: nouveaux regards (Études réunies en l'honneur de Jacques Jouanna), ed. V. BoudonMillot, A. Guardasole and C. Magdelaine, 73-123. Paris, 2007.

Boudon-Millot, V. 'Galen's Bios and Methodos: From Ways of Life to Path of Knowledge'. In Galen and the World of Knowledge, ed. C. Gill, T. Whitmarsh and J. Wilkins, 175-89. Cambridge: CUP, 2009 .

Boudon-Millot, V. (ed., trans. and notes) Galien, Tome I, Paris: Les Belles Lettres, 2007. 
Boudon-Millot, V. and Pietrobelli, A. 'Galien ressucité: édition princeps du texts grec du De propriis placitis', Revue des Études Grecques 118 (2005), 168-213.

Boudon-Millot, V. and Jouanna, J. (ed. and trans.), with A. Pietrobelli, Galien, Oeuvres, 4: Ne pas se chagriner. Paris: Les Belles Lettres, 2010.

Dorandi, T. Le stylet et la tablette: dans le secret des auteurs antiques. Paris: Les Belles Lettres, 2000.

Dorandi, T. Le Nell' officina dei classici: come lavorano gli autori antichi. Rome: Carocci, 2007.

van der Eijk, P. 'Galen and the Scientific Treatise: A Case Study of Mixtures'. In Writing Science: Medical and Mathematical Authorship in Ancient Greece, ed. M. Asper, in collaboration with A.-M. Kanthak, 145-75, Science, Technology and Medicine in Ancient Cultures 1. Berlin: de Gruyter, 2013.

Gill, C., Whitmarsh, T. and Wilkins, J. (eds) Galen and the World of Knowledge. Cambridge: CuP, 2009.

Gleason, M. W. Making Men: Sophists and Self-Presentation in Ancient Rome. Princeton, New Jersey: Princeton University Press, 1995.

Gourinat, J.-B. 'Le Platon de Panétius: à propos d'un témoignage inédit de Galien', Philosophie Antique 8 (2008), 139-51.

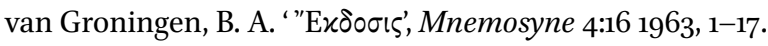

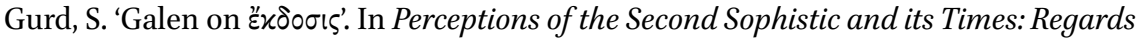
sur la seconde sophistique et son époque, ed. T. Schmidt and P. Fleury, 169-84. Toronto University of Toronto Press, 2011.

König, J. 'Conventions of Prefatory Self-Presentation in Galen's On the Order of My Own Books'. In Galen and the World of Knowledge, ed. C. Gill, T. Whitmarsh and J. Wilkins, 35-58. Cambridge: CUP, 2009.

Manetti, D. (ed.) Studi sul De indolentia di Galeno, Pisa and Rome: Fabrizio Serra Editore, 2012

Manetti, D. and Roselli, A. 'Galeno commentatore di Ippocrate'. In ANRW II.37.2 (1994), 1529-1635.

Mansfeld, J. 'Galen's Autobibliographies and Hippocratic Commentaries'. In Prolegomena: Questions to be Settled Before the Study of an Author, or a Text. Leiden, New York and Cologne: Brill, 1994.

Manuli, P. and Vegetti, M. (eds). Le opere psicologiche di Galeno: atti del terzo Colloquio Galenico Internazionale, Pavia, 1986. Naples: Bibliopolis, 1988.

del Mastro, G. (2012). 'M $\varepsilon$ $\gamma \alpha \beta ı \beta \lambda$ ov: Galeno e la lunghezza dei libri'. In Studi sul De indolentia di Galeno, ed. D. Manetti, 33-62. Pisa and Rome: Fabrizio Serra Editore, 2012.

Mattern, S. P. Galen and the Rhetoric of Healing. Baltimore: The Johns Hopkins University Press, 2008.

Peterson, D. W. 'Observations on the Chronology of the Galenic Corpus', Bulletin of the History of Medicine 51 (1977), 484-95. 
Singer, P. N. Galen: Selected Works. Translation with introduction and notes. Oxford: OUP, 1997.

Singer, P. N. (ed.) Galen: Psychological Writings: Avoiding Distress, The Diagnosis and Treatment of Affections and Errors Peculiar to Each Person's Soul, Character Traits and The Capacities of the Soul Depend on the Mixtures of the Body, translated with introduction and notes by V. Nutton, D. Davies and P. N. Singer, with the collaboration of Piero Tassinari. Cambridge: CUP, 2013.

Starr, R. J. 'The Circulation of Literary Texts in the Ancient World', cQ 37 (1987), 213-23. von Staden, H. 'Gattung und Gedächtnis: Galen über Wahrheit und Lehrdichtung'. In Gattungen wissenschaftlicher Literatur in der Antike, ed. W. Kullmann, J. Althoff, M. Asper (eds), 65-94. Tübingen, 1998.

von Staden, H. 'Staging the Past, Staging Oneself: Galen on Hellenistic Exegetical

Traditions'. In Galen and the World of Knowledge, ed. C. Gill, T. Whitmarsh and J. Wilkins, 132-56. Cambridge: CUP, 2009.

Vegetti, M. Galeno: nuovi scritti autobiografici. Rome: Carocci editore, 2013.

\section{Texts: Editions, Translations and Abbreviations}

\section{Ammonius}

In Cat. = In Aristotelis Categorias. Ed. A. Busse: Berlin, CAG IV.4, 1895.

\section{Galen}

Texts of Galen are cited by volume and page number in Kühn's edition (where available), followed by page and line number in the most recent critical edition, if different.

K. = C. G. Kühn, Claudii Galeni Opera Omnia, 22 vols. Leipzig, 1821-1833.

CMG = Corpus Medicorum Graecorum, Leipzig and Berlin, 1908-.

$A A=$ De anatomicis administrationibus (Anatomical Procedures). [K. II] .

Aff. Pecc. Dig. 1 and 2 = De propriorum animi cuiuslibet affectuum dignotione et curatione and De animi cuiuslibet peccatorum dignotione et curatione (Affections and Errors of the Soul). [K. v]. Ed. W. de Boer. Berlin and Leipzig: Teubner, CM G V 4,1,1, 1937; trans. in Singer, Galen: Psychological Writings.

Comp. Med. Gen. = De compositione medicamentorum per genera. [K. XIII].

De crisibus (Crises). [K. Ix].

De diebus decretoribus (Critical Days). [K. IX].

Hipp. Art. = In Hippocratis De Articulis, [K. XVIIIA].

Hipp. Epid. III = In Hipporatis Epidemiarum librum III (Commentary on Hippocrates 'Epidemics III'). [K. XVIIA]. Ed. E. Wenkebach. Leipzig and Berlin: Teubner, CMG V $10,2,1,1936$. 
Hipp. Epid. VI = In Hippocratis Epidemiarum librum VI (Commentary on Hippocrates 'Epidemics VI'). [K. XVIIA-B (partial)]. Ed./German trans. E. Wenkebach and E. Pfaff. Berlin: Akademie Verlag, CMG V 10,2,2, 1956.

Hipp. Off. Med = In Hippocratis De officina Medica. [K. XVIIIB]. Ed. (Arabic) M. Lyons. Berlin: Akademie Verlag (CMg Suppl. Or. 1), 1963.

$H N H=$ In Hippocratis De natura hominis. [K.Xv]. Ed. J. Mewaldt. Leipzig and Berlin: Teubner, CMG V 9,1, 1914.

Ind. = De indolentia (Perialupias). [Not in K.]. Ed. V. Boudon-Millot and J. Jouanna, with the collaboration of A. Pietrobelli: Ne pas se chagriner. Paris: Les Belles Lettres, 2010 (BJP); trans. by V. Nutton in Singer, Galen: Psychological Writings.

Lib. Prop. = De libris propriis (My Own Books). [K. XIX]. Ed. V. Boudon-Millot. Paris: Les Belles Lettres, 2007; trans. in Singer, Galen: Selected Works.

Loc. Aff. = De locis affectis (Affected Places). [K. VIII]. Books 1 and 2 ed. F. Gärtner. Berlin:

De Gruyter, CMG V 6,1,1, 2015 .

$M M=$ De methodo medendi (The Therapeutic Method). [K. X]. Trans. I. Johnston and

G. H. R. Horsley. Cambridge, Mass.: Harvard University Press (Loeb), 2011.

Ord. Lib. Prop. = De ordine librorum propriorum (The Order of My Own Books). [K. XIX].

Ed. V. Boudon-Millot. Paris: Les Belles Lettres, 2007; trans. in Singer, Galen: Selected Works.

PHP = De placitis Hippocratis et Platonis (The Doctrines of Hippocrates and Plato). [K. v]. Ed. and trans. P. De Lacy, 3 vols. Berlin: Akademie Verlag, CMG V 4,1,2, 1978-84. In Plat. Tim. = In Platonis Timaeum Commentarii Fragmenta. [Not in K.] Ed. H. O. Schröder. Berlin and Leipzig: Teubner, cm Suppl. I, 1934.

Praen. = De praenotione ad Epigenem (Prognosis). [K. XIV]. Ed. and trans. V. Nutton. Berlin: Akademie Verlag, CMG v 8,1, 1979.

Prop. Plac. $=$ De propriis placitis (My Own Doctrines). [Not in K.] Ed. and trans. V. Nutton. Berlin: Akademie Verlag (CMG V 3,2), 1999. Ed. and French trans. of fuller text by V. Boudon-Millot and A. Pietrobelli, A., 'Galien ressucité: édition princeps du texte grec du De propriis placitis', Revue des Études Grecques 118 (2005), 168-213. Ed. with Italian trans. by I. Garofalo and A. Lami, Galeno: L' anima e il dolore. Milan: Rizzoli, 2012. Italian trans. by M. Vegetti, Galeno: nuovi scritti autobiografici. Rome: Carocci, 2013.

$Q A M=$ Quod animi mores corporis temperamenta sequantur. (The Soul's Dependence on the Body). [K. IV]. Ed. I. Müller, in C. Galeni Scripta Minora, 2. Leipzig: Teubner, 1891; trans. in Singer, Galen: Psychological Writings.

San. Tu. = De sanitate tuenda. (Matters of Health). [K. vI]. Ed. K. Koch. Berlin and Leipzig: Teubner, CMG V 4,2, 1923.

$U P=$ De usu partium. [K. III-IV]. Ed. G. Helmreich, 2 vols. Leipzig: Teubner, 1907-9.

Iamblichus

Vit. Pyth. = De vita pythagorica 